\title{
A high-voltage rechargeable magnesium-sodium hybrid battery
}

Yifei Li ${ }^{\mathrm{a}, 1}$, Qinyou An ${ }^{\mathrm{a}, 1}$, Yingwen Cheng ${ }^{\mathrm{b}, 1}$, Yanliang Liang ${ }^{\mathrm{a}}$, Yang Ren ${ }^{\mathrm{c}}$, Cheng-Jun Sun ${ }^{\mathrm{c}}$, Hui Dong $^{\mathrm{a}}$, Zhongjia Tang ${ }^{\mathrm{d}, \mathrm{e}}$, Guosheng $\mathrm{Li}^{\mathrm{b}, *}$, and Yan Yao,e,*

${ }^{a}$ Department of Electrical and Computer Engineering and Materials Science and Engineering Program, University of Houston, Houston, Texas 77204, USA ${ }^{b}$ Electrochemical Materials and Systems Group, Energy and Environment Directorate, Pacific Northwest National Laboratory, Richland, Washington 99354, USA ${ }^{c} X$-ray Science Division, Argonne National Laboratory, Argonne, Illinois 60439, USA ${ }^{d}$ Department of Chemistry, University of Houston, Houston, Texas 77204, USA ${ }^{e}$ Texas Center for Superconductivity at University of Houston, Houston, Texas 77204, USA

* Correspondence author at: Department of Electrical and Computer Engineering and Materials Science and Engineering Program, University of Houston, Houston, TX 77204, USA (Y. Yao) and Electrochemical Materials and Systems Group, Energy and Environment Directorate, Pacific Northwest National Laboratory, Richland, Washington 99354, USA (G. Li).

E-mail addresses: Guosheng.Li@pnnl.gov (G. Li); yyao4@uh.edu (Y. Yao)

${ }^{1}$ These authors contributed equally to this work. 


\section{ABSTRACT}

Growing global demand of safe and low-cost energy storage technology triggers strong interests in novel battery concepts beyond state-of-art Li-ion batteries. Here we report a high-voltage rechargeable $\mathrm{Mg}-\mathrm{Na}$ hybrid battery featuring dendrite-free deposition of $\mathrm{Mg}$ anode and $\mathrm{Na}$ intercalation cathode as a low-cost and safe alternative to Li-ion batteries for large-scale energy storage. A prototype device using a $\mathrm{Na}_{3} \mathrm{~V}_{2}\left(\mathrm{PO}_{4}\right)_{3}$ cathode, a $\mathrm{Mg}$ anode, and a $\mathrm{Mg}-\mathrm{Na}$ dual salt electrolyte exhibits the highest voltage $(2.60 \mathrm{~V}$ vs. $\mathrm{Mg})$ and best rate performance (86\% capacity retention at 10C rate) among reported hybrid batteries. Synchrotron radiation-based X-ray absorption near edge structure (XANES), atomic-pair distribution function (PDF), and highresolution X-ray diffraction (HRXRD) studies reveal the chemical environment and structural change of $\mathrm{Na}_{3} \mathrm{~V}_{2}\left(\mathrm{PO}_{4}\right)_{3}$ cathode during the $\mathrm{Na}$ ion insertion/deinsertion process. XANES study shows a clear reversible shift of vanadium K-edge and HRXRD and PDF studies reveal a reversible two-phase transformation and $\mathrm{V}-\mathrm{O}$ bond length change during cycling. The energy density of the hybrid cell could be further improved by developing electrolytes with a higher salt concentration and wider electrochemical window. This work represents a significant step forward for practical safe and low-cost hybrid batteries.

Keywords: hybrid $\mathrm{Mg}-\mathrm{Na}$ ion battery, $\mathrm{Na}_{3} \mathrm{~V}_{2}\left(\mathrm{PO}_{4}\right)_{3}, \mathrm{Mg}$, XANES, pair density function 


\section{Introduction}

Developing affordable high-energy density rechargeable batteries is a global priority to meet the increasing demand of electric transportation and grid energy storage. Currently commercialized high-energy-density lithium-ion batteries (LIBs) are the dominant technology, but the high cost and safety concerns of LIB present disadvantages [1]. The price of lithium carbonate, an essential raw material for LIB cathodes, had a significant rise in 2015 due to its growing global demand for the energy storage application. Therefore, high energy density, prolonged cycle life, and most importantly, low materials and manufacturing cost are strongly desired for beyond-LIB energy storage technologies, thus triggering strong interests in novel battery concepts such as multivalent ion $\left(\mathrm{Mg}^{2+}, \mathrm{Ca}^{2+}\right.$, and $\left.\mathrm{Al}^{3+}\right)$ intercalation batteries [2-4].

Magnesium metal is a promising anode material for rechargeable batteries, which possesses a low reduction potential ( $-2.37 \mathrm{~V}$ vs. SHE), high volumetric capacity $\left(3833 \mathrm{mAh} \mathrm{cm}^{-3}\right)$, natural abundance, and fast dendrite-free deposition/stripping kinetics [3, 5-7]. Mg rechargeable batteries (MRB) have attracted considerable interest in the past few years and resulted in advancement in novel electrolytes [3, 8-10] and fundamental understanding of the electro-active species in such electrolytes [11]. Despite the progress, development of practical MRB remains hindered largely due to the limited choices of $\mathrm{Mg}$-intercalation cathodes and anode-electrolytecathode incompatibility $[5,12]$. Recent breakthrough from Nazar's group on thiospinel cathode demonstrated high specific capacity of $190 \mathrm{mAh} \mathrm{g}^{-1}$ at $0.2 \mathrm{C}$ at an elevated temperature of $60{ }^{\circ} \mathrm{C}$, however, the voltage is still lower than $1.5 \mathrm{~V}$ [13].

On the other hand, rechargeable $\mathrm{Mg}-\mathrm{Li}$ hybrid batteries and their $\mathrm{Mg}-\mathrm{Na}$ analogues have attracted substantial attentions because of its advantages as have been outlined in detail in our 
recent review article [14]. In particular, this hybrid design could integrate the advantages of the $\mathrm{Mg}$ metal anode and the $\mathrm{Li}^{+} / \mathrm{Na}^{+}$intercalation cathode for providing a device much better safety, rate capability and cycling stability. Particularly, $\mathrm{Mg} / \mathrm{Na}$ hybrid battery system has potential advantage in low cost by replacing $\mathrm{Li}$ cathode with $\mathrm{Na}$ cathode. However, almost all reports show low cell voltage less than $1.5 \mathrm{~V}$ vs. $\mathrm{Mg} / \mathrm{Mg}^{2+}$. The energy density of a battery is proportional to its voltage, therefore, hybrid devices with voltage higher than $2.0 \mathrm{~V}$ is strongly desired for practical applications. Significant challenges towards high voltage include poor cathode-electrolyte compatibility and limited stability of the electrolyte. These characteristics lead to low Coulombic efficiency due to decomposition of the electrolyte, sluggish ion desolvation and transport across the interface [14]. Kovalenko and coworkers recently reported the first $\mathrm{Mg}-\mathrm{Na}$ hybrid cell using $\mathrm{FeS}_{2}$ nanocrystal cathode [15]. The cell has a sloping voltage profile from 1.6 to $0.4 \mathrm{~V}$ vs. $\mathrm{Mg}$ with an average discharge voltage of $\sim 1.1 \mathrm{~V}$.

In this work, we report a rechargeable $\mathrm{Mg}-\mathrm{Na}$ hybrid battery which shows a higher voltage than state-of-art $\mathrm{Mg}-\mathrm{Na}$ hybrid cell. The hybrid cell using a $\mathrm{Na}_{3} \mathrm{~V}_{2}\left(\mathrm{PO}_{4}\right)_{3}$ cathode, a $\mathrm{Mg}$ anode, and a $\mathrm{Mg}-\mathrm{Na}$ dual salt electrolyte exhibits the highest voltage $(2.60 \mathrm{~V}$ vs. $\mathrm{Mg}$ ) and best rate performance ( $86 \%$ capacity retention at $10 \mathrm{C}$ rate) among reported hybrid cells. We investigated the phase transformation and change of oxidation state of vanadium (V) using synchrotron radiation-based X-ray characterizations. Notably, a shrinkage-expansion behavior of the $\mathrm{Na}_{3} \mathrm{~V}_{2}\left(\mathrm{PO}_{4}\right)_{3}$ structure and changes of various atomic bonding lengths $(\mathrm{V}-\mathrm{O}, \mathrm{P}-\mathrm{O}, \mathrm{Na}-\mathrm{O}$, etc.) during battery reaction were first identified, which are very difficult to observe by conventional characterization techniques.

\section{Experimental section}




\subsection{Synthesis of Carbon-coated $\mathrm{Na}_{3} \mathrm{~V}_{2}\left(\mathrm{PO}_{4}\right)_{3}$}

$\mathrm{V}_{2} \mathrm{O}_{5}(0.364 \mathrm{~g})$ and $\mathrm{H}_{2} \mathrm{C}_{2} \mathrm{O}_{4} \cdot 2 \mathrm{H}_{2} \mathrm{O}(0.76 \mathrm{~g})$ were dissolved into deionized water $(20 \mathrm{~mL})$ and vigorously stirred at $70{ }^{\circ} \mathrm{C}$ for $1 \mathrm{~h}$ to obtain a $\mathrm{VOC}_{2} \mathrm{O}_{4}$ solution. Then $\mathrm{NaH}_{2} \mathrm{PO}_{4}(0.72 \mathrm{~g})$ and glucose $(0.2 \mathrm{~g})$ were added into the solution, which was further stirred for $5 \mathrm{~min}$. N-propanol (50 $\mathrm{mL}$ ) was further added under stirring for $30 \mathrm{~min}$, followed by drying at $70{ }^{\circ} \mathrm{C}$ to obtain the precursor. Finally, $\mathrm{Na}_{3} \mathrm{~V}_{2}\left(\mathrm{PO}_{4}\right)_{3} / \mathrm{C}$ micro-composites were obtained from the precursor by preheating at $400{ }^{\circ} \mathrm{C}$ for 4 hours and annealing at $750{ }^{\circ} \mathrm{C}$ for $8 \mathrm{~h}$ in $\mathrm{Ar}$ atmosphere with a heating rate of $5{ }^{\circ} \mathrm{C} \mathrm{min}^{-1}$.

\subsection{Preparation of Electrolytes}

The electrolyte synthesis was carried out in an Ar-filled glove box. In a typical synthesis of

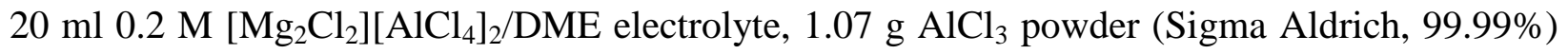
was added slowly (exothermic reaction) to a suspension of $\mathrm{MgCl}_{2}$ (Alfa Aesar, 99.999\%, $0.76 \mathrm{~g}$ in $20 \mathrm{ml}$ DME) in a $25 \mathrm{ml}$ glass vial. The mixture was stirred at $60^{\circ} \mathrm{C}$ using a sand bath for 6 hours and was cooled to room temperature. A clear solution was obtained with no precipitants. The hybrid-ion electrolytes were prepared by dissolving appropriate amount of $\mathrm{NaAlCl}_{4}$ (Alfa Aesar) into the above electrolyte.

\subsection{Preparation of Electrodes}

The positive electrode was prepared by first mixing a slurry containing $70 \mathrm{wt} \%$ active material, $20 \mathrm{wt} \%$ super-P carbon and $10 \mathrm{wt} \%$ polyvinylidene fluoride (PVDF) binder, and the proper amount of N-methyl-2-pyrrolidone (NMP) as dispersant. The slurry was then coated on Mo foil $\left(0.8 \mathrm{~cm}^{2}\right)$. The NMP was removed by first drying the electrode at $70{ }^{\circ} \mathrm{C}$ for $2 \mathrm{~h}$ and then further drying the electrode in a vacuum oven at $120{ }^{\circ} \mathrm{C}$ for another $2 \mathrm{~h}$. Mass loading of the 


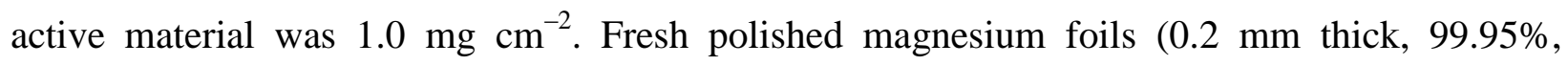
GalliumSource, LLC, Scotts Valley, CA) were used as both the counter and reference electrodes. In synchrotron X-ray based measurements, poly(tetrafluoroethylene) (PTFE) was used as the binder with a higher active mass loading of $4 \mathrm{mg} \mathrm{cm}^{-2}$.

\subsection{Materials Characterization}

Tubular sealed three-electrode cells were fabricated for electrochemical characterizations. The cells were assembled in an Ar-filled glove box. Electrochemical characterizations were conducted using a potentiostat (VMP-3, Bio-Logic Co., Claix, France). Specific capacity was calculated based on the mass of active material in the cathode. Scanning electron microscopy (SEM) and energy-dispersive X-ray spectroscopy (EDX) measurements were conducted using a JEOL JSM 6400 SEM with an Octane Silicon Drift Detector (EDAX, model: OCTANE PRO). Transmission electron microscopy (TEM) was measured with JEM-2100F. Weight percentage of carbon in the carbon coated $\mathrm{Na}_{3} \mathrm{~V}_{2}\left(\mathrm{PO}_{4}\right)_{3}$ was obtained by thermogravimetric analysis (TGA, TA instruments Q50).

\subsection{High-resolution X-ray Diffraction (HRXRD)}

HRXRD experiments were performed at Beamline 12-BM in Advanced Photon Source at Argonne National Laboratory. The wavelength of the synchrotron X-ray beam was $0.4137 \AA$. The powder samples were sealed into the Kapton capillaries with a diameter of $1 \mathrm{~mm}$. During the measurement, the capillary was rotated and the diffracted X-ray was collected by 12 detectors simultaneously. Finally, the obtained patterns from the 12 detectors were combined together to generate high-resolution XRD spectra.

2.6. X-ray Absorption Spectroscopy $(X A S)$ 
The XAS measurement for V K-edge was carried out in fluorescence mode at Beamline 20BM. The incident beam was monochromatized using a Si(111) fixed-exit, double-crystal monochromator. Materials to be measured were pressed into a pellet sealed with 50 - $\mu$ m-thick Kapton tape. One V foil was measured simultaneously with target samples for the purpose of calibration. X-ray absorption near edge structure (XANES) spectra were further analyzed to explore the changes of oxidation state of $\mathrm{V}$ in the $\mathrm{Na}_{3} \mathrm{~V}_{2}\left(\mathrm{PO}_{4}\right)_{3} / \mathrm{NaV}_{2}\left(\mathrm{PO}_{4}\right)_{3}$ samples. In the XANES analysis, normalization and linear combination were conducted using the Athena software package [16].

\subsection{Pair Distribution Function Analysis (PDF)}

PDF experiments were conducted at Beamline 11 ID-C. The samples were sealed into the Kapton capillaries. The wavelength of the X-ray source was $0.1174 \AA$ with the energy of 105.1 $\mathrm{keV}$, and the beam size was $0.2 \mathrm{~mm} \times 0.2 \mathrm{~mm}$. A Perkin Elmer area detector was used to obtain two-dimensional (2D) diffraction patterns in the transmission geometry, with the distance between the detector and measured sample of about $340 \mathrm{~mm} . \mathrm{CeO}_{2}$ standard sample packed inside the capillary was measured for the purpose of calibration. In order to avoid saturation of the detector, each measurement was carried out in multiple exposures. Each sample was exposed to X-ray more than three times to improve the counting statistics, and the obtained 2D patterns from multiple exposure for each sample were combined and integrated into one dimensional (1D) data using the Fit2D program. Data from an empty Kapton capillary was also collected to subtract the container scattering. The total scattering structure function was then obtained from the converted 1D data using the program PDFgetX2. Finally, the PDF or G(r) in real space was obtained by Fourier transformation of the total scattering intensities I(Q), which is a function of the wave vector $\mathrm{Q}(4 \pi \sin \theta / \lambda)$ of the samples. For example, if $\mathrm{a}$ and $\mathrm{b}$ are two particles in $\mathrm{a}$ 
medium, the PDF of $b$ with respect to $a$, denoted by $G(r)$, is the probability of finding the particle $\mathrm{b}$ at the distance $\mathrm{r}$ from $\mathrm{a}$.

\section{Results and discussion}

The operating principle of a rechargeable $\mathrm{Mg}-\mathrm{Na}$ hybrid battery is illustrated in Fig. 1a. Because the thermodynamic redox potential of $\mathrm{Mg}^{2+} / \mathrm{Mg}$ is $0.36 \mathrm{~V}$ higher than that $\mathrm{fa}^{+} / \mathrm{Na}$, reversible $\mathrm{Mg}$ deposition takes place at the anode side before $\mathrm{Na}$ deposition could occur. On the cathode side, $\mathrm{Na}$-ion is believed to dominate the intercalation because the diffusivity of $\mathrm{Mg}^{2+}$ is typically several orders of magnitude slower compared to that of $\mathrm{Na}^{+}$in the same host material [17]. The selection of a suitable hybrid electrolyte is critical for obtaining high energy density and stable cycling. Due to the high anodic stability of magnesiumchloro dimer complex electrolyte (stable up to $3.4 \mathrm{~V}$ vs. $\mathrm{Mg}$ ) [8], we prepared $0.2 \mathrm{M}\left[\mathrm{Mg}_{2}(\mu-\mathrm{Cl})_{2}\right]\left[\mathrm{AlCl}_{4}\right]_{2}$ in dimethoxythane (DME) and then dissolved $0.4 \mathrm{M} \mathrm{NaAlCl}_{4}$ to form a transparent hybrid electrolyte (Fig. S1). The solubility of $\mathrm{NaAlCl}_{4}$ in this electrolyte is about $0.5 \mathrm{M}$ at room temperature. The flow of electroactive species during the charging process is shown in Fig. 1b.

$\mathrm{Na}_{3} \mathrm{~V}_{2}\left(\mathrm{PO}_{4}\right)_{3}$ has a NASICON framework with large interstitial space for reversible $\mathrm{Na}^{+}$ insertion [18-21]. Carbon-coating is usually applied on $\mathrm{Na}_{3} \mathrm{~V}_{2}\left(\mathrm{PO}_{4}\right)_{3}$ nanoparticles due to pristine $\mathrm{Na}_{3} \mathrm{~V}_{2}\left(\mathrm{PO}_{4}\right)_{3}$ being an electronic insulator [22, 23]. Hu and coworkers demonstrated stable cycling with a reversible capacity of $107 \mathrm{mAh} \mathrm{g}^{-1}$ [18]. Carbon-coated $\mathrm{Na}_{3} \mathrm{~V}_{2}\left(\mathrm{PO}_{4}\right)_{3}$ was therefore synthesized and the morphology was investigated by SEM. As shown in Fig. 2a, $\mathrm{Na}_{3} \mathrm{~V}_{2}\left(\mathrm{PO}_{4}\right)_{3}$ appears as homogeneous flower-like microspheres (1-2 $\mu \mathrm{m}$ in diameter) assembled by nanoflakes with a thickness of $20-50 \mathrm{~nm}$. The nanoflakes are loosely interconnected, offering open spaces between them. During the synthesis process, $\mathrm{V}_{2} \mathrm{O}_{5}$ and $\mathrm{NaH}_{2} \mathrm{PO}_{4}$ were chosen as vanadium and phosphorus precursors, respectively (details of the synthesis procedure can be 
found in the Experimental section). Glucose was added to not only help maintain the morphology of intermediate product during annealing [24], but also serve as the source for carbon coating [22]. HRTEM further displays the lattice fringes with high crystallinity and the $d$ spacing of $0.37 \mathrm{~nm}$, corresponding to the (113) planes of $\mathrm{Na}_{3} \mathrm{~V}_{2}\left(\mathrm{PO}_{4}\right)_{3}$ (Fig. 2b). The carbon layer can be well observed, with a thickness of about $5 \mathrm{~nm}$. The carbon amount on $\mathrm{Na}_{3} \mathrm{~V}_{2}\left(\mathrm{PO}_{4}\right)_{3}$ is 3.1 wt.\% calculated from TGA measurement (Fig. S2).

The electrochemical properties of the pure $\mathrm{Mg}$ electrolyte $\left(0.2 \mathrm{M}\left[\mathrm{Mg}_{2}(\mu-\mathrm{Cl})_{2}\right]\left[\mathrm{AlCl}_{4}\right]_{2}\right.$ in $\mathrm{DME}$ ) and the hybrid electrolyte were investigated via cyclic voltammetry (CV) using a threeelectrode setup, and typical profiles are shown in Fig. 2c. The pure $\mathrm{Mg}$ electrolyte has remarkable properties for reversible $\mathrm{Mg}$ deposition/stripping and shows a Coulombic efficiency of $88 \%$ (inset of Fig. 2c) and stable electrochemical window up to $3.2 \mathrm{~V}$ vs. $\mathrm{Mg}$ on Mo substrate [8]. Addition of $0.4 \mathrm{M} \mathrm{NaAlCl}_{4}$ results in slightly enhanced activity, characterized by slightly reduced $\mathrm{Mg}$ deposition over-potential to $-0.15 \mathrm{~V}$ and enhanced Coulombic efficiency of $89 \%$. Overall, the performance of $\mathrm{Mg}$ anode is not impaired by the use of a hybrid electrolyte. The origin of the improved activity is not yet clear, but we believe two factors could contribute to the difference: (i) the increases in ionic conductivity with addition of $\mathrm{NaAlCl}_{4}$, and (ii) the increased concentration of $\mathrm{AlCl}_{4}{ }^{-}$anion that could modify the $\mathrm{Mg}$-metal and electrolyte interfacial properties that makes deposition and stripping of $\mathrm{Mg}$ more favorable. Furthermore, we also note that similar phenomenon with enhanced electrochemical properties was observed with the addition of Li salts [30].

The electrochemical performance of $\mathrm{Na}_{3} \mathrm{~V}_{2}\left(\mathrm{PO}_{4}\right)_{3}$ was first investigated in the pure $\mathrm{Mg}$ electrolyte. Molybdenum (Mo) foil is used as the current collector for all cells in this work due to its anti-corrosion property [25]. As shown in Fig. $\mathrm{S} 3 \mathrm{a}, \mathrm{Na}_{3} \mathrm{~V}_{2}\left(\mathrm{PO}_{4}\right)_{3}$ was first charged to 
deintercalate $\mathrm{Na}$ ions to become $\mathrm{NaV}_{2}\left(\mathrm{PO}_{4}\right)_{3}$ at the rate of $0.2 \mathrm{C}\left(1 \mathrm{C}=118 \mathrm{~mA} \mathrm{~g}{ }^{-1}\right)$, with a charge capacity of $114 \mathrm{mAh} \mathrm{g}^{-1}$. During this process, $\mathrm{Na}$ ions are extracted from the $\mathrm{Na}_{3} \mathrm{~V}_{2}\left(\mathrm{PO}_{4}\right)_{3}$ framework into the $\mathrm{Mg}$ electrolyte:

$$
\mathrm{Na}_{3} \mathrm{~V}_{2}\left(\mathrm{PO}_{4}\right)_{3}-2 \mathrm{e}^{-} \rightarrow \mathrm{NaV}_{2}\left(\mathrm{PO}_{4}\right)_{3}+2 \mathrm{Na}^{+}
$$

Then the $\mathrm{Mg}$ electrolyte containing the deintercalated $\mathrm{Na}$ ions was replaced with a fresh $\mathrm{Mg}$ electrolyte, and the produced $\mathrm{NaV}_{2}\left(\mathrm{PO}_{4}\right)_{3}$ continued to be discharged and charged at the same rate in the subsequent cycles. The capacity was only $\sim 7 \mathrm{mAh} \mathrm{g}^{-1}$, implying that $\mathrm{Mg}$ ions are very difficult to get intercalated into $\mathrm{NaV}_{2}\left(\mathrm{PO}_{4}\right)_{3}$ vacant sites after desodiation, which possibly results from the strong coulombic interactions between $\mathrm{Mg}$ ions and $\mathrm{NaV}_{2}\left(\mathrm{PO}_{4}\right)_{3}$ framework. However, if the electrolyte containing $\mathrm{Na}$ ions was not replaced after the first charge, a reversible capacity of about $41 \mathrm{mAh} \mathrm{g}^{-1}$ could be obtained. This indicate that the $\mathrm{Na}$ ions deintercalated from $\mathrm{Na}_{3} \mathrm{~V}_{2}\left(\mathrm{PO}_{4}\right)_{3}$ cathode can deliver the capacity partially but are not enough to demonstrate the maximum capacity. To make full advantage of the cathode capacity, a hybrid electrolyte with adding a suitable amount of $\mathrm{Na}$ ions is necessary. $\mathrm{Na}_{3} \mathrm{~V}_{2}\left(\mathrm{PO}_{4}\right)_{3}$ was thus charged first in a $\mathrm{Mg}-$ $\mathrm{Na}$ hybrid electrolyte (Fig. S3b). Then the desodiated $\mathrm{NaV}_{2}\left(\mathrm{PO}_{4}\right)_{3}$ was washed by DME solvent and cycled in a fresh hybrid electrolyte for the following cycles to avoid the formation of $\mathrm{NaCl}$, which was found difficult to dissolve completely in the hybrid electrolyte. Fig. S3b shows the galvanostatic voltage profile of $\mathrm{NaV}_{2}\left(\mathrm{PO}_{4}\right)_{3}$ in the $\mathrm{Mg}-\mathrm{Na}$ hybrid electrolyte with a voltage window of 1.6-3.0 $\mathrm{V}$ under the current density of $1 \mathrm{C}\left(118 \mathrm{~mA} \mathrm{~g}^{-1}\right)$. The first discharge capacity of $\mathrm{NaV}_{2}\left(\mathrm{PO}_{4}\right)_{3}$ is $104 \mathrm{mAh} \mathrm{g}^{-1}$. Fig. $2 \mathrm{~d}$ reveals the first three cycles of galvanostatic voltage profiles for the $\mathrm{NaV}_{2}\left(\mathrm{PO}_{4}\right)_{3}$ cathode and $\mathrm{Mg}$ anode measured simultaneously in a three-electrode setup. At $1 \mathrm{C}$ rate, the $\mathrm{NaV}_{2}\left(\mathrm{PO}_{4}\right)_{3}$ shows a voltage plateau at $2.6 \mathrm{~V}$ vs. $\mathrm{Mg}$ with very small overpotential. For the $\mathrm{Mg}$ anode side, the overpotential for $\mathrm{Mg}$ deposition/dissolution is less than 
$0.15 \mathrm{~V}$. In order to realize the high voltage, we integrated several of our successful demonstrations on $\mathrm{Mg}$ batteries, including advanced $\mathrm{Mg}$ electrolytes with wider electrochemical window (>3.2V), corrosion resistive Mo current collector, [25] and the customized Swagelok battery cells. [30] The proper combination of these findings as demonstrated in this work ensures the highest voltage among reported hybrid batteries. A summary of reported Mg hybrid batteries is shown in Table $\mathrm{S} 1$.

During the discharge process, Na-ions are inserted into $\mathrm{NaV}_{2}\left(\mathrm{PO}_{4}\right)_{3}$ framework from the hybrid electrolyte, and simultaneously metallic $\mathrm{Mg}$ anode reacts with $\mathrm{AlCl}_{4}{ }^{-}$to form $\left[\mathrm{Mg}_{2} \mathrm{Cl}_{2}\right]^{2+}$ dimer cations and $\mathrm{AlCl}_{3}$ because $\mathrm{AlCl}_{4}^{-}$is easier to lose $\mathrm{Cl}^{-}$than $\mathrm{MgCl}^{+}$. This process is accompanied by electrons moving through the external circuit to maintain the charge neutrality. $\mathrm{No} \mathrm{NaCl}$ will be formed due to no free $\mathrm{Cl}^{-}$available, which is different from the initial charge process. The following equations describe the reactions in the cell:

Positive electrode: $\mathrm{NaV}_{2}\left(\mathrm{PO}_{4}\right)_{3}+2 \mathrm{Na}^{+}+2 \mathrm{e}^{-} \leftrightarrow \mathrm{Na}_{3} \mathrm{~V}_{2}\left(\mathrm{PO}_{4}\right)_{3}$

Negative electrode: $\mathrm{Mg}+\mathrm{AlCl}_{4}^{-} \leftrightarrow 1 / 2\left[\mathrm{Mg}_{2} \mathrm{Cl}_{2}\right]^{2+}+\mathrm{AlCl}_{3}+2 \mathrm{e}^{-}$

Overall reaction: $\mathrm{NaV}_{2}\left(\mathrm{PO}_{4}\right)_{3}+2 \mathrm{NaAlCl}_{4}+\mathrm{Mg} \leftrightarrow \mathrm{Na}_{3} \mathrm{~V}_{2}\left(\mathrm{PO}_{4}\right)_{3}+1 / 2\left[\mathrm{Mg}_{2} \mathrm{Cl}_{2}\right]\left[\mathrm{AlCl}_{4}\right]_{2}+\mathrm{AlCl}_{3}$ It is observed that most of the capacity is contributed by a long plateau at about $2.60 \mathrm{~V}$, which is associated with a two-phase reaction between $\mathrm{Na}_{3} \mathrm{~V}_{2}\left(\mathrm{PO}_{4}\right)_{3}$ and $\mathrm{NaV}_{2}\left(\mathrm{PO}_{4}\right)_{3}$ [18]. Electrochemical impedance spectra (EIS) (Fig. S4) on $\mathrm{NaV}_{2}\left(\mathrm{PO}_{4}\right)_{3}$ further reveals the difference in the charge transfer resistance ( $R_{\mathrm{ct}}$, characterized by a semicircle in the high frequency region) between the pure $\mathrm{Mg}$ electrolyte and $\mathrm{Mg}-\mathrm{Na}$ hybrid electrolyte in a three-electrode setup. The $R_{\mathrm{ct}}$ corresponds to 80 vs. $30 \mathrm{ohms}$, respectively, indicating a more efficient charge transfer when $\mathrm{Na}$ ions are present in the electrolyte [26]. Fig. 2e shows the cycling stability with $81.2 \%$ capacity retention for 50 cycles. The corresponding Coulombic efficiency is $97.6 \%$ on the first cycle and 
slowly increases to $98.7 \%$ on the 50th cycle. After 50 cycles, the $\mathrm{Mg}$ anode was investigated under SEM and EDX spectroscopy. No dendrite-like feature of Mg metals is observed (Fig. S5). No $\mathrm{Na}$ is detected from EDX, indicating no $\mathrm{Na}$ deposition during Mg deposition/dissolution (Fig. 2f).

The rate capability of $\mathrm{NaV}_{2}\left(\mathrm{PO}_{4}\right)_{3}$ in the $\mathrm{Mg}-\mathrm{Na}$ hybrid battery is shown in Fig. 3a. At $0.5 \mathrm{C}$, it reveals specific capacity of $100.7 \mathrm{mAh} \mathrm{g}^{-1}$ and average discharge voltage of $\sim 2.60 \mathrm{~V}$. It is noteworthy that $\mathrm{NaV}_{2}\left(\mathrm{PO}_{4}\right)_{3}$ can retain $99.8,98.4,91$, and $86 \%$ of the initial capacity at $0.5 \mathrm{C}$ when the rate is increased to $1,2,5$, and 10C, respectively (Fig. 3b). This remarkable rate performance is related to the fast diffusion kinetics of $\mathrm{Na}$ ions in the open framework of $\mathrm{NaV}_{2}\left(\mathrm{PO}_{4}\right)_{3}$, similar with that in $\mathrm{Na}$ ion batteries. This rate retention is higher than all of the reported hybrid batteries (see Fig. $3 b$ and other details in Table S1) [15, 26-32]. For example, $\mathrm{FeS}_{2}$, as one of the very few reported cathodes for $\mathrm{Mg}-\mathrm{Na}$ hybrid batteries, shows a lower capacity retention of $70 \%$ when the rate is increased from $0.2 \mathrm{C}$ to $2 \mathrm{C}$ [15]. A voltage-capacity plot is shown in Fig. 3c, where our work represents the highest operational voltage. Even though other materials show higher specific capacities, most of them were obtained at low rate as shown in Fig. 3b. The corresponding energy density of the $\mathrm{Mg}-\mathrm{Na}$ hybrid battery was calculated to be $150 \mathrm{Wh} \mathrm{kg}^{-1}$ at $1 \mathrm{C}$ considering the weight of salt in electrolyte (see Supplementary Text), and the power density is $1.51 \mathrm{~kW} \mathrm{~kg}^{-1}$ at $10 \mathrm{C}$, higher than most of the previous hybrid batteries including the $\mathrm{TiS}_{2} \mathrm{Mg}-\mathrm{Li}$ hybrid battery from our group [28].

To shed light on the structure change of $\mathrm{Na}_{3} \mathrm{~V}_{2}\left(\mathrm{PO}_{4}\right)_{3} / \mathrm{NaV}_{2}\left(\mathrm{PO}_{4}\right)_{3}$ during the $\mathrm{Na}$ ions (de)insertion process in the hybrid battery, synchrotron X-ray based techniques were carried out. Six samples each at different state of charge were prepared (Fig. 4a). HRXRD spectra were shown in Fig. 4 b. For the pristine $\mathrm{Na}_{3} \mathrm{~V}_{2}\left(\mathrm{PO}_{4}\right)_{3}$ (stage 1), all peaks can be indexed to the 
NASICON structure. Benefiting from the high resolution feature, each peak is well indexed. For example, (104) and (110) peaks are completely separated, while they are typically hard to be separated in conventional XRD [18, 20,33]. New peaks corresponding to a second phase appear in stage 2 and coexists with the peaks of $\mathrm{Na}_{3} \mathrm{~V}_{2}\left(\mathrm{PO}_{4}\right)_{3}$ phase, indicating a two-phase reaction. Analysis on this sample shows that the new peaks are identical to those for $\mathrm{NaV}_{2}\left(\mathrm{PO}_{4}\right)_{3}$ phase [18]. At stage 3 when the sample was fully charged, the intensities of the new peaks become much sharper while those from $\mathrm{Na}_{3} \mathrm{~V}_{2}\left(\mathrm{PO}_{4}\right)_{3}$ disappear completely. Then, with a following halfdischarge to stage 4 (by controlling the discharge capacity to be half as that for a full discharge), the two-phase transformation happens again. At stage 5, the sample was fully discharged, and all of the peaks return to the original $\mathrm{Na}_{3} \mathrm{~V}_{2}\left(\mathrm{PO}_{4}\right)_{3}$ phase. At stage 6 where sample was charged halfway, the two-phase feature appeared again. According to the identical XRD patterns for fully discharged stages 1 and 5, we conclude that Na-ion storage in $\mathrm{Na}_{3} \mathrm{~V}_{2}\left(\mathrm{PO}_{4}\right)_{3}$ involves a reversible two-phase transformation in the hybrid system.

In addition to the phase evolution, electronic structures of the six $\mathrm{Na}_{3} \mathrm{~V}_{2}\left(\mathrm{PO}_{4}\right)_{3}$ samples were also deciphered via XANES. Fig. $4 \mathrm{c}$ shows the XANES of the six samples at V K-edge, which is associated with the $1 \mathrm{~s}$ to unoccupied $4 \mathrm{p}$ electronic transition [34]. It is found that V K-edge at about $5473-5476 \mathrm{eV}$ shifted to higher energy of $5480-5483 \mathrm{eV}$ upon charging from stage 1 to 3 , indicating a partial oxidation of $\mathrm{V}$ from $\mathrm{V}^{3+}$ in $\mathrm{Na}_{3} \mathrm{~V}_{2}\left(\mathrm{PO}_{4}\right)_{3}$ to $\mathrm{V}^{4+}$ in $\mathrm{NaV}_{2}\left(\mathrm{PO}_{4}\right)_{3}$. The K-edge shifted back to lower energies when discharged from stage 3 to 5 , corresponding to the reduction of V. It is also evident that the position of V K-edge was the lowest (5473-5476 eV) at fully discharged stages 1 and 5, highest (5480-5483 eV) at the fully charged stage 3, and lies inbetween $(5477-5480 \mathrm{eV})$ for the half-charged/discharged stages 2,4 , and 6 . The valence state of $\mathrm{V}$ at each stage was quantitatively calculated by linear regression analysis based on stages 1 and 
3 (Table S2). Because the valence number of $\mathrm{V}$ is 3 at stage 1 and 4 at stage 3 , the valence number at stages 2, 4, 5 and 6 is calculated to be $3.58,3.33,3.10$ and 3.38 , respectively. These results suggest that the charge compensation in $\mathrm{Na}_{3} \mathrm{~V}_{2}\left(\mathrm{PO}_{4}\right)_{3} / \mathrm{NaV}_{2}\left(\mathrm{PO}_{4}\right)_{3}$ upon $\mathrm{Na}^{+}$ (de)intercalation was mainly achieved by the change of oxidation state of V. XAS spectra of the six samples at broader energy range is also shown in Fig. S6, where the calibration of the absorption intensities can be seen.

We went on to gain structural insights by studying the specific bonding length change of $\mathrm{Na}_{3} \mathrm{~V}_{2}\left(\mathrm{PO}_{4}\right)_{3} / \mathrm{NaV}_{2}\left(\mathrm{PO}_{4}\right)_{3}$ in the hybrid system via PDF analysis, which describes the distribution of distances between pairs of atoms within a given volume. By virtue of the high energy X-ray (105.1 keV), PDF analysis has excellent resolving ability at small radial distance for crystalline and even amorphous frameworks [35-37]. Fig. 5c shows the G(r), the PDFs in real space obtained from a Fourier transform of the scattering intensities as a function of the wave vector of the samples. From the PDF results, we identify a peak at $2.035 \AA$ at stages 1 and 5, which shifts to $1.85 \AA$ at stage 3 . Both peaks exist at stages 2,4 and 6 . These peaks are attributed to the nearest $\mathrm{V}-\mathrm{O}$ atomic pairs or bonds, as shown in Fig. 5b. Therefore, the mean $\mathrm{V}-\mathrm{O}$ distance of desodiated samples is shorter than that of the sodiated samples, and this agrees well with the argument that smaller $\mathrm{V}^{4+}$ ions exist in the $\mathrm{NaV}_{2}\left(\mathrm{PO}_{4}\right)_{3}$ phase and larger $\mathrm{V}^{3+}$ ions exist in the $\mathrm{Na}_{3} \mathrm{~V}_{2}\left(\mathrm{PO}_{4}\right)_{3}$ phase. Analysis of the intensities of the peaks at 1.85 and $2.035 \AA$ shows the ratio of the two distinct $\mathrm{V}-\mathrm{O}$ bonds in each sample (Fig. $5 \mathrm{~d}$ and Table $\mathrm{S} 3$ ). The percentage of the $\mathrm{V}-\mathrm{O}$ bonds with a distance of $\sim 1.85 \AA$ in stages $1-6$ is $0,31.3,62.6,21.0,17.9$ and $32.0 \%$, respectively. It is reasonable to state that the $\mathrm{V}-\mathrm{O}$ bond length change is reversible, which resembles the phase transformation and valence number change. The peaks at $1.52 \AA$ arise from the $\mathrm{P}-\mathrm{O}$ atomic pairs, and do not change in these samples, indicating a stable $\mathrm{P}-\mathrm{O}$ tetragonal 
structure (Fig. 5b). The distance of $\mathrm{V}-\mathrm{P}$ interatomic pairs is determined by both $\mathrm{V}-\mathrm{O}$ and $\mathrm{P}-\mathrm{O}$ bonds as shown in Fig. 5b. Since $\mathrm{P}-\mathrm{O}$ bonds are invariable, the $\mathrm{V}-\mathrm{P}$ distance behaves in a similar way as V-O bonds, characterized by the peak at 3.33-3.39 ̊. Note that there are two sites where $\mathrm{Na}$ ions occupy in $\mathrm{Na}_{3} \mathrm{~V}_{2}\left(\mathrm{PO}_{4}\right)_{3}$. $\mathrm{Na}$ ions on $6 \mathrm{~b}$ position are immobile while those on 18e are mobile during charging process, and they are denoted as $\mathrm{Na} 1$ and $\mathrm{Na} 2$, respectively (Fig. 5a). The immobile Na1 ions stabilize the $\mathrm{Na}_{3} \mathrm{~V}_{2}\left(\mathrm{PO}_{4}\right)_{3}$ structure, and thereby show an unchanged peak at $2.50 \AA$ for Na1-O pairs. Interestingly, the peak at $8.79 \AA$ A shows identical trend as that for V-O pairs, shifting from 8.78 (stage 1) to $8.50 \AA$ (stage 3) and recovering to $8.78 \AA$ at stage 5 . This peak is associated to the Na1-Na1 atomic pairs, which have similar distance with the lattice parameter $a(8.73 \AA)$. Thus, the shrinkage and expansion of $\mathrm{Na}_{3} \mathrm{~V}_{2}\left(\mathrm{PO}_{4}\right)_{3}$ framework in $a$ direction is reported which is related to the change of $\mathrm{V}-\mathrm{O}$ bond lengths. Overall, PDF analysis is a powerful tool to understand how $\mathrm{Na}_{3} \mathrm{~V}_{2}\left(\mathrm{PO}_{4}\right)_{3}$ structure changes during cycling in the hybrid battery.

\section{Conclusion}

In summary, we report a $\mathrm{Mg}-\mathrm{Na}$ hybrid battery using $\mathrm{Mg}$ anode, a high-voltage cathode $\mathrm{Na}_{3} \mathrm{~V}_{2}\left(\mathrm{PO}_{4}\right)_{3}$, and a dual salt and non-nucleophilic $\mathrm{Mg}-\mathrm{Na}$ electrolyte. The hybrid cell based on desodiated $\mathrm{NaV}_{2}\left(\mathrm{PO}_{4}\right)_{3}$ displays a capacity of $\sim 100 \mathrm{mAh} \mathrm{g}^{-1}$, a working voltage of $\sim 2.60 \mathrm{~V}$, and rate capability of $86 \%$ at $10 \mathrm{C}$ compared with that at $0.5 \mathrm{C}$. Both the voltage and rate retention are higher than any previously reported hybrid batteries. The remarkable electrochemical performance arises from the fast and highly reversible $\mathrm{Na}$-ions(de)intercalation at $\mathrm{NaV}_{2}\left(\mathrm{PO}_{4}\right)_{3}$ cathode and stable electrolyte with high anti-oxidation capability. Furthermore, the Na-ion uptake and removal process at $\mathrm{NaV}_{2}\left(\mathrm{PO}_{4}\right)_{3}$ have been studied by synchrotron $\mathrm{X}$-ray-based techniques. HRXRD and PDF clearly reveal the reversible phase transition and the change of 
bond lengths on the $\mathrm{NaV}_{2}\left(\mathrm{PO}_{4}\right)_{3}$ framework. XAS confirms that $\mathrm{V}$ atoms are reversibly involved in the redox reaction. This work showcases a successful method to construct Mg-based hybrid batteries, which will advance the development of safe and low-cost large-scale energy storage technology.

\section{Acknowledgements}

Y.Y. acknowledges the funding support from the US Office of Naval Research Award (N0001413-1-0543) and the National Science Foundation (CMMI-1400261). G. L. acknowledges the support by the U.S. Department of Energy (DOE) Office of Electricity Delivery and Energy

Reliability for the electrolyte synthesis under Contract No. 57558. Sector 20 facilities at the Advanced Photon Source, and research at these facilities, are supported by the US Department of Energy - Basic Energy Sciences, the Canadian Light Source and its funding partners, and the Advanced Photon Source. This research used resources of the Advanced Photon Source, a U.S. Department of Energy (DOE) Office of Science User Facility operated for the DOE Office of Science by Argonne National Laboratory under Contract No. DE-AC02-06CH11357.

\section{Appendix A. Supporting information}

Supplementary data associated with this article can be found in the online version at doi:XXX/j.nanoen.XXX.

\section{References}

[1] M. Armand, J. M. Tarascon, Nature 451 (2008) 652-657.

[2] H. D. Yoo, I. Shterenberg, Y. Gofer, G. Gershinsky, N. Pour, D. Aurbach, Energy Environ. Sci. 6 (2013) 2265-2279.

[3] J. Muldoon, C. B. Bucur, T. Gregory, Chem. Rev. 114 (2014) 11683-11720.

[4] M.-C. Lin, M. Gong, B. Lu, Y. Wu, D.-Y. Wang, M. Guan, M. Angell, C. Chen, J. Yang, B.-J. Hwang, H. Dai, Nature 520 (2015) 324-328. 
[5] D. Aurbach, Z. Lu, A. Schechter, Y. Gofer, H. Gizbar, R. Turgeman, Y. Cohen, M. Moshkovich, E. Levi, Nature 407 (2000) 724-727.

[6] Y. Liang, H. D. Yoo, Y. Li, J. Shuai, H. A. Calderon, F. C. Robles Hernandez, L. C. Grabow, Y. Yao, Nano Lett. 15 (2015) 2194-2202.

[7] R. Zhang, C. Ling, MRS Energy \& Sustainability 3 (2016).

[8] Y. Cheng, R. M. Stolley, K. S. Han, Y. Shao, B. W. Arey, N. M. Washton, K. T. Mueller, M. L. Helm, V. L. Sprenkle, J. Liu, G. Li, Phys. Chem. Chem. Phys. 17 (2015) 1330713314.

[9] S. G. McArthur, L. Geng, J. Guo, V. Lavallo, Inorganic Chemistry Frontiers 2 (2015) 1101-1104.

[10] O. Tutusaus, R. Mohtadi, T. S. Arthur, F. Mizuno, E. G. Nelson, Y. V. Sevryugina, Angew. Chem. Int. Ed. 54 (2015) 7900-7904.

[11] P. Canepa, S. Jayaraman, L. Cheng, N. N. Rajput, W. D. Richards, G. S. Gautam, L. A. Curtiss, K. A. Persson, G. Ceder, Energy Environ. Sci. 8 (2015) 3718-3730.

[12] I. Shterenberg, M. Salama, Y. Gofer, E. Levi, D. Aurbach, MRS Bulletin 39 (2014) 453460.

[13] X. Sun, P. Bonnick, V. Duffort, M. Liu, Z. Rong, K. A. Persson, G. Ceder, L. F. Nazar, Energy Environ. Sci. 9 (2016) 2273-2277.

[14] Y. Cheng, H. J. Chang, H. Dong, D. Choi, V. L. Sprenkle, J. Liu, Y. Yao, G. Li, J. Mater. Res. 31 (2016) 3125-3141.

[15] M. Walter, K. V. Kravchyk, M. Ibáñez, M. V. Kovalenko, Chem. Mater. 27 (2015) $7452-$ 7458.

[16] B. Ravel, M. Newville, Journal of Synchrotron Radiation 12 (2005) 537-541.

[17] J. Shuai, H. D. Yoo, Y. Liang, Y. Li, Y. Yao, L. C. Grabow, Mater. Res. Express 3 (2016) 064001.

[18] Z. Jian, W. Han, X. Lu, H. Yang, Y.-S. Hu, J. Zhou, Z. Zhou, J. Li, W. Chen, D. Chen, L. Chen, Adv. Energy Mater. 3 (2013) 156-160.

[19] K. Saravanan, C. W. Mason, A. Rudola, K. H. Wong, P. Balaya, Adv. Energy Mater. 3 (2013) 444-450.

[20] Y. Jiang, Z. Yang, W. Li, L. Zeng, F. Pan, M. Wang, X. Wei, G. Hu, L. Gu, Y. Yu, Adv. Energy Mater. 5 (2015) 1402104.

[21] G. Li, Z. Yang, Y. Jiang, C. Jin, W. Huang, X. Ding, Y. Huang, Nano Energy 25 (2016) 211-217.

[22] C. Zhu, K. Song, P. A. van Aken, J. Maier, Y. Yu, Nano Lett. 14 (2014) 2175-2180.

[23] W. Ren, Z. Zheng, C. Xu, C. Niu, Q. Wei, Q. An, K. Zhao, M. Yan, M. Qin, L. Mai, Nano Energy 25 (2016) 145-153.

[24] Q. An, F. Xiong, Q. Wei, J. Sheng, L. He, D. Ma, Y. Yao, L. Mai, Adv. Energy Mater. 5 (2015) 1401963.

[25] Y. Cheng, T. Liu, Y. Shao, M. H. Engelhard, J. Liu, G. Li, J. Mater. Chem. A 2 (2014) 2473-2477.

[26] T. Gao, F. Han, Y. Zhu, L. Suo, C. Luo, K. Xu, C. Wang, Adv. Energy Mater. 5 (2015) 1401507.

[27] Y. Zhang, J. Xie, Y. Han, C. Li, Adv. Funct. Mater. 25 (2015) 7300-7308.

[28] H. D. Yoo, Y. Liang, Y. Li, Y. Yao, ACS Appl. Mater. Interfaces 7 (2015) 7001-7007.

[29] Z. Zhang, H. Xu, Z. Cui, P. Hu, J. Chai, H. Du, J. He, J. Zhang, X. Zhou, P. Han, G. Cui, L. Chen, J. Mater. Chem. A 4 (2016) 2277-2285. 
[30] Y. Cheng, D. Choi, K. S. Han, K. T. Mueller, J.-G. Zhang, V. L. Sprenkle, J. Liu, G. Li, Chem. Commun. 52 (2016) 5379-5382.

[31] Y. Cheng, Y. Shao, J.-G. Zhang, V. L. Sprenkle, J. Liu, G. Li, Chem. Commun. 50 (2014) 9644-9646.

[32] Q. Miao, Y. NuLi, N. Wang, J. Yang, J. Wang, S.-i. Hirano, RSC Adv. 6 (2016) 32313234.

[33] Y. H. Jung, C. H. Lim, D. K. Kim, J. Mater. Chem. A 1 (2013) 11350-11354.

[34] E. Uchaker, Y. Z. Zheng, S. Li, S. L. Candelaria, S. Hu, G. Z. Cao, J. Mater. Chem. A 2 (2014) 18208-18214.

[35] V. Petkov, P. N. Trikalitis, E. S. Bozin, S. J. L. Billinge, T. Vogt, M. G. Kanatzidis, J. Am. Chem. Soc. 124 (2002) 10157-10162.

[36] M. Moriya, M. Miyahara, M. Hokazono, H. Sasaki, A. Nemoto, S. Katayama, Y. Akimoto, S.-i. Hirano, Y. Ren, J. Power Sources 263 (2014) 7-12.

[37] T. Proffen, S. J. L. Billinge, J. Appl. Crystallogr. 32 (1999) 572-575. 


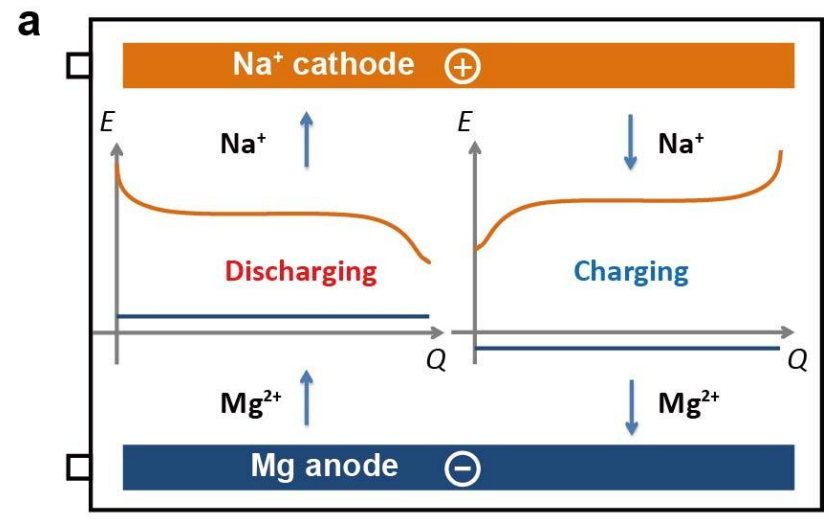

b

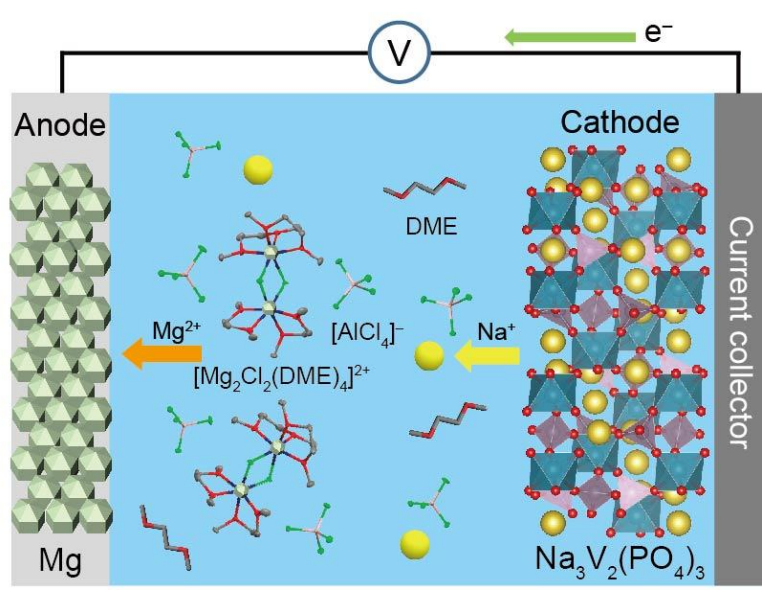

Fig. 1. (a) Illustration of the operating principle of a $\mathrm{Mg}-\mathrm{Na}$ hybrid battery. During battery discharging, $\mathrm{Na}^{+}$ions intercalate into the cathode and $\mathrm{Mg}^{2+}$ ions dissolve from a $\mathrm{Mg}$ anode. The corresponding voltage profiles of the positive and negative electrodes are shown in orange and blue lines, respectively. (b) Electro-active species involved during charging a hybrid battery made of a $\mathrm{Na}_{3} \mathrm{~V}_{2}\left(\mathrm{PO}_{4}\right)_{3}$ cathode, a $\mathrm{Mg}$ anode, and an electrolyte of $0.2 \mathrm{M}\left[\mathrm{Mg}_{2} \mathrm{Cl}_{2}\right]\left[\mathrm{AlCl}_{4}\right]_{2}$ and $0.4 \mathrm{M} \mathrm{NaAlCl}_{4}$ in DME. 

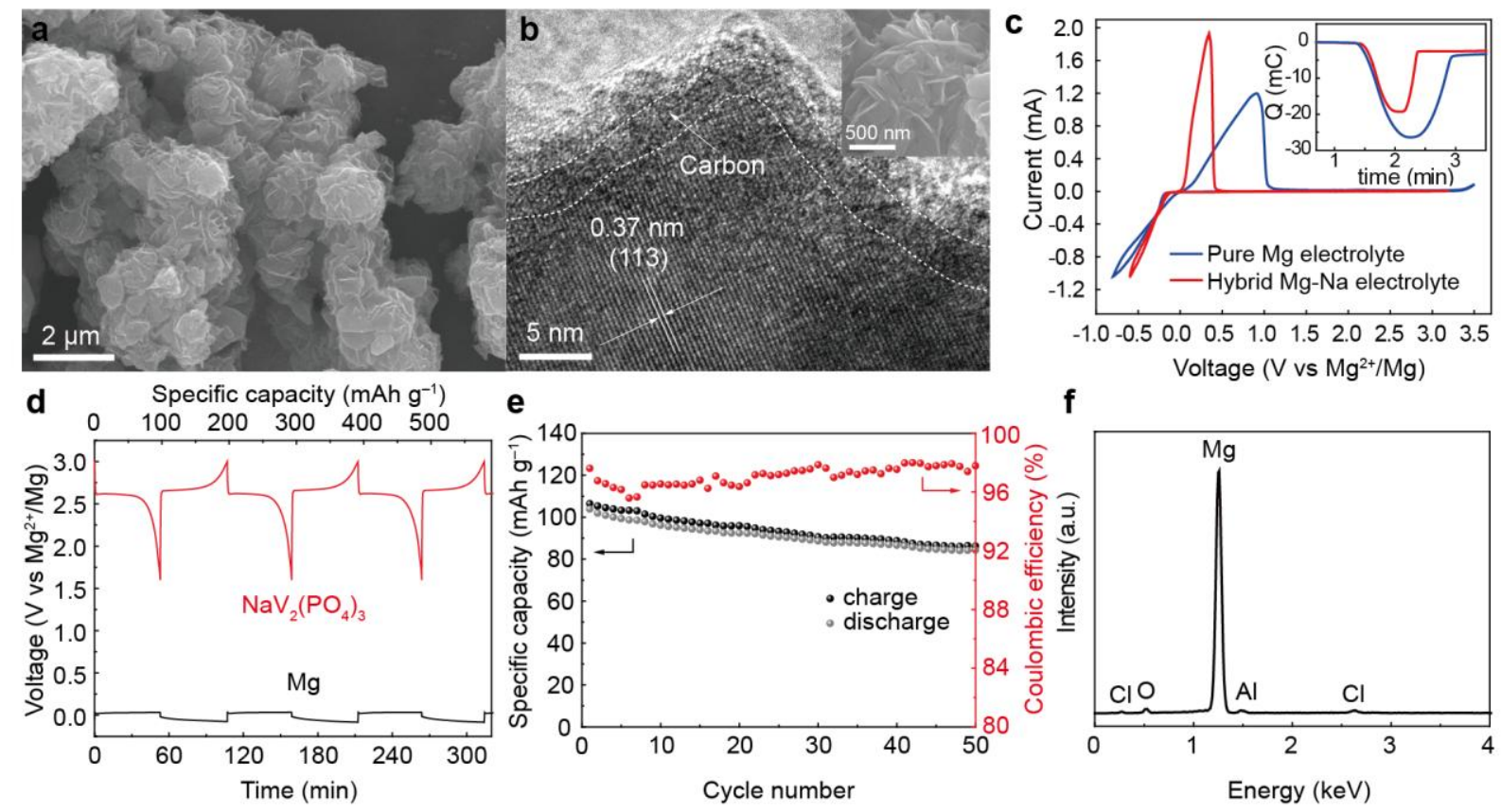

Fig. 2. (a) SEM and (b) TEM images of carbon-coated $\mathrm{Na}_{3} \mathrm{~V}_{2}\left(\mathrm{PO}_{4}\right)_{3}$ particles. (c) Cyclic voltammograms of a pure $\mathrm{Mg}$ electrolyte and a hybrid $\mathrm{Mg}-\mathrm{Na}$ electrolyte at a scan rate of 25 $\mathrm{mV} \mathrm{s}^{-1}$ in a three-electrode cell. Inset shows the accumulated charge during $\mathrm{Mg}$ deposition-dissolution cycle. (d) The voltage profiles for the first three galvanostatic cycles for the $\mathrm{Na}_{3} \mathrm{~V}_{2}\left(\mathrm{PO}_{4}\right)_{3}$ cathode (red) and $\mathrm{Mg}$ anode (black) in a three-electrode cell setup. (e) Capacity retention and coulombic efficiency over 50 cycles at 1C-rate cycling. (f) EDS spectrum of $\mathrm{Mg}$ anode after 50 cycles of $\mathrm{Mg}$ deposition/dissolution. 

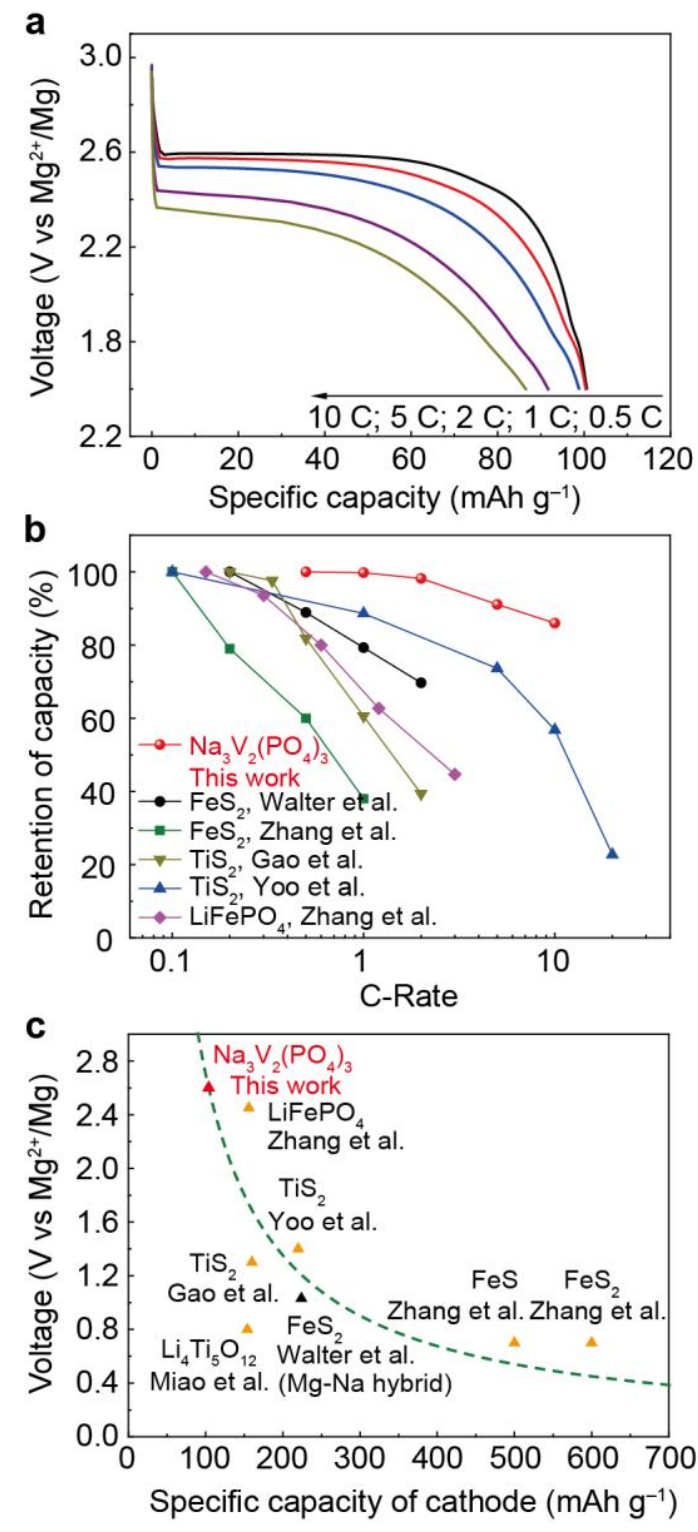

Fig. 3. (a) Discharge voltage profiles of a $\mathrm{Na}_{3} \mathrm{~V}_{2}\left(\mathrm{PO}_{4}\right)_{3}-\mathrm{Mg}$ hybrid cell at various C-rates $(0.5,1$, 2, 5, and 10 C). (b) Specific capacity retention at various C-rates in comparison with reported hybrid cells. (c) The voltage-specific capacity plot. Black triangle shows reported $\mathrm{Mg}-\mathrm{Na}$ hybrid cell. Yellow triangles show reported Mg-Li hybrid cells. Specific capacity is calculated based on the mass of active material in the cathode. 
a

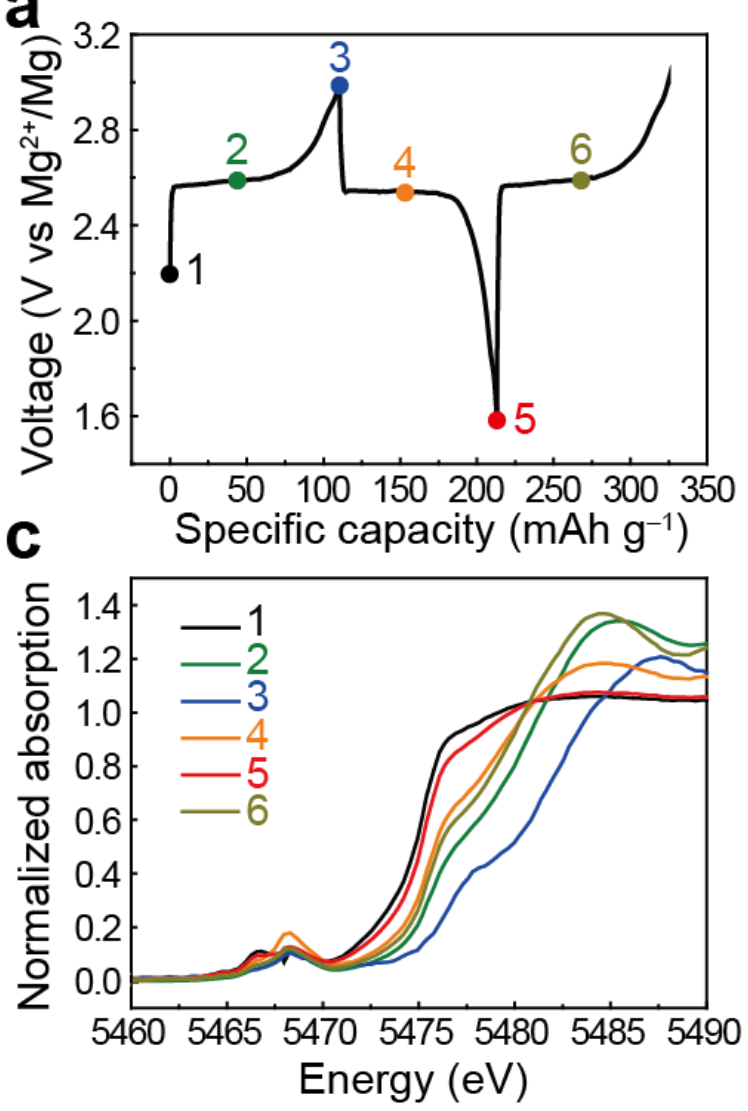

b

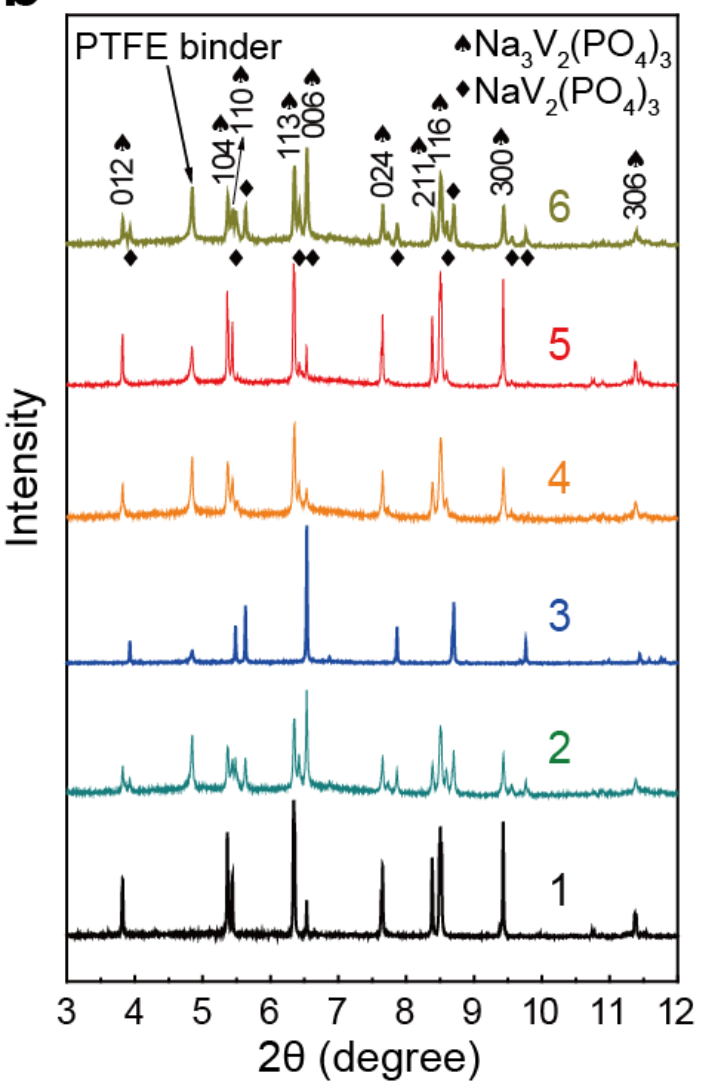

Fig. 4. Ex-situ HRXRD and XANES characterizations of $\mathrm{Na}_{3} \mathrm{~V}_{2}\left(\mathrm{PO}_{4}\right)_{3} / \mathrm{NaV}_{2}\left(\mathrm{PO}_{4}\right)_{3}$ electrodes at various state-of-charge. (a) Galvanostatic voltage profile shows the specific state of samples 1-6. (b) ex-situ HRXRD measurements. Peaks from the $\mathrm{Na}_{3} \mathrm{~V}_{2}\left(\mathrm{PO}_{4}\right)_{3}$ and $\mathrm{NaV}_{2}\left(\mathrm{PO}_{4}\right)_{3}$ phases are labeled as $\wedge$ and $\bullet$, respectively. (c) Vanadium K-edge of XANES spectra of $\mathrm{Na}_{3} \mathrm{~V}_{2}\left(\mathrm{PO}_{4}\right)_{3}$ stages $1-6$. 


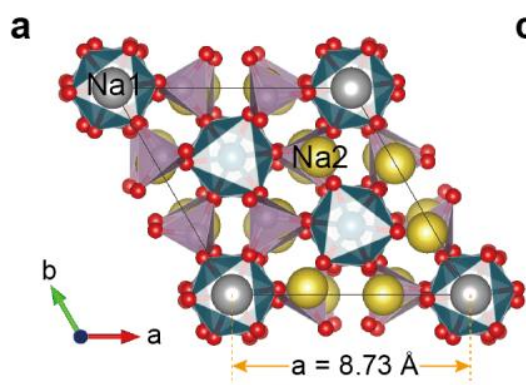

b

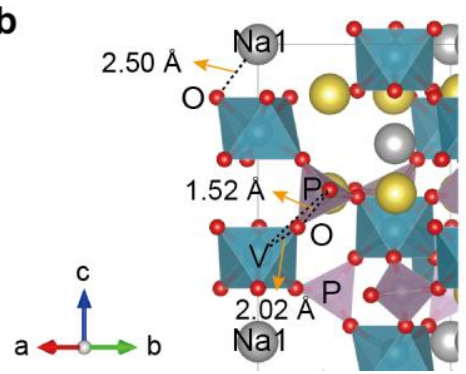

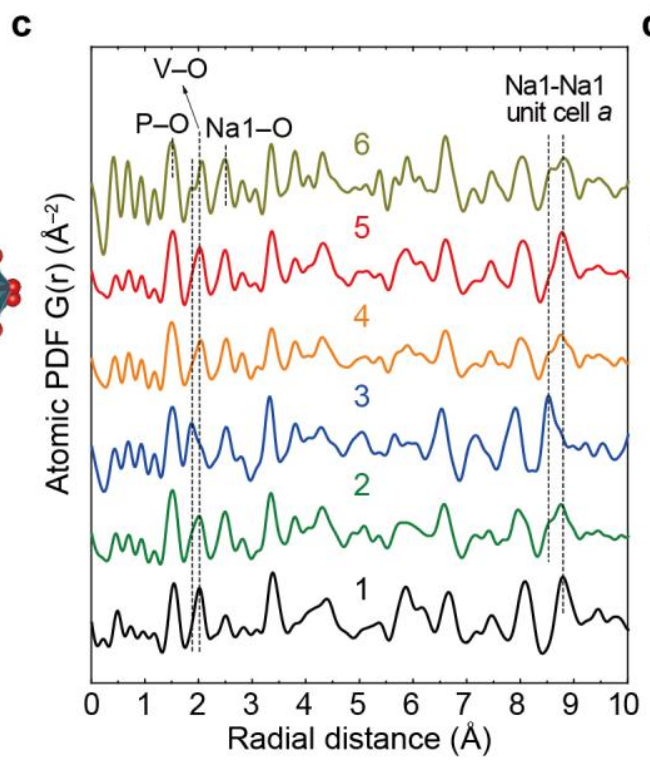

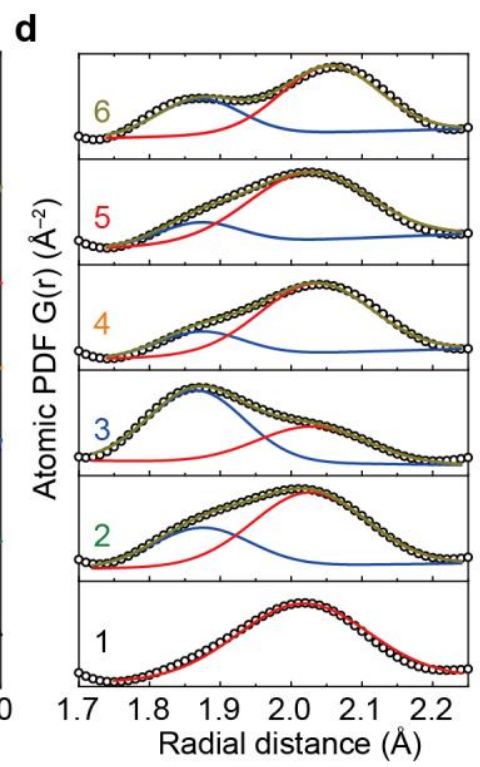

Fig. 5. $\mathrm{PDF}$ analysis for $\mathrm{Na}_{3} \mathrm{~V}_{2}\left(\mathrm{PO}_{4}\right)_{3}$ samples 1-6 at various state-of-charge. (a) Crystal structure of $\mathrm{Na}_{3} \mathrm{~V}_{2}\left(\mathrm{PO}_{4}\right)_{3}$ in [001] direction. $\mathrm{Na} 1$ and $\mathrm{Na} 2$ are shown as gray and yellow spheres, respectively. (b) Crystal structure of $\mathrm{Na}_{3} \mathrm{~V}_{2}\left(\mathrm{PO}_{4}\right)_{3}$ in [110] direction. $\mathrm{Na1}$ atoms function as immobile pillars and stabilize the host structure. (c) PDF spectra with peaks corresponding to interatomic distances of P-O (1.52 $\AA$ ), V-O (2.02 $\AA$ ), and $\mathrm{Na}_{1}-\mathrm{O}(2.50 \AA)$ are highlighted with dashed lines. (d) Magnified spectra reveal the ratio of $\mathrm{V}^{3+}-\mathrm{O}$ (blue, $1.85 \AA$ ) and $\mathrm{V}^{4+}-\mathrm{O}$ (red, 2.03 A) in stages $1-6$. 
Figure 1
Click here to download high resolution image

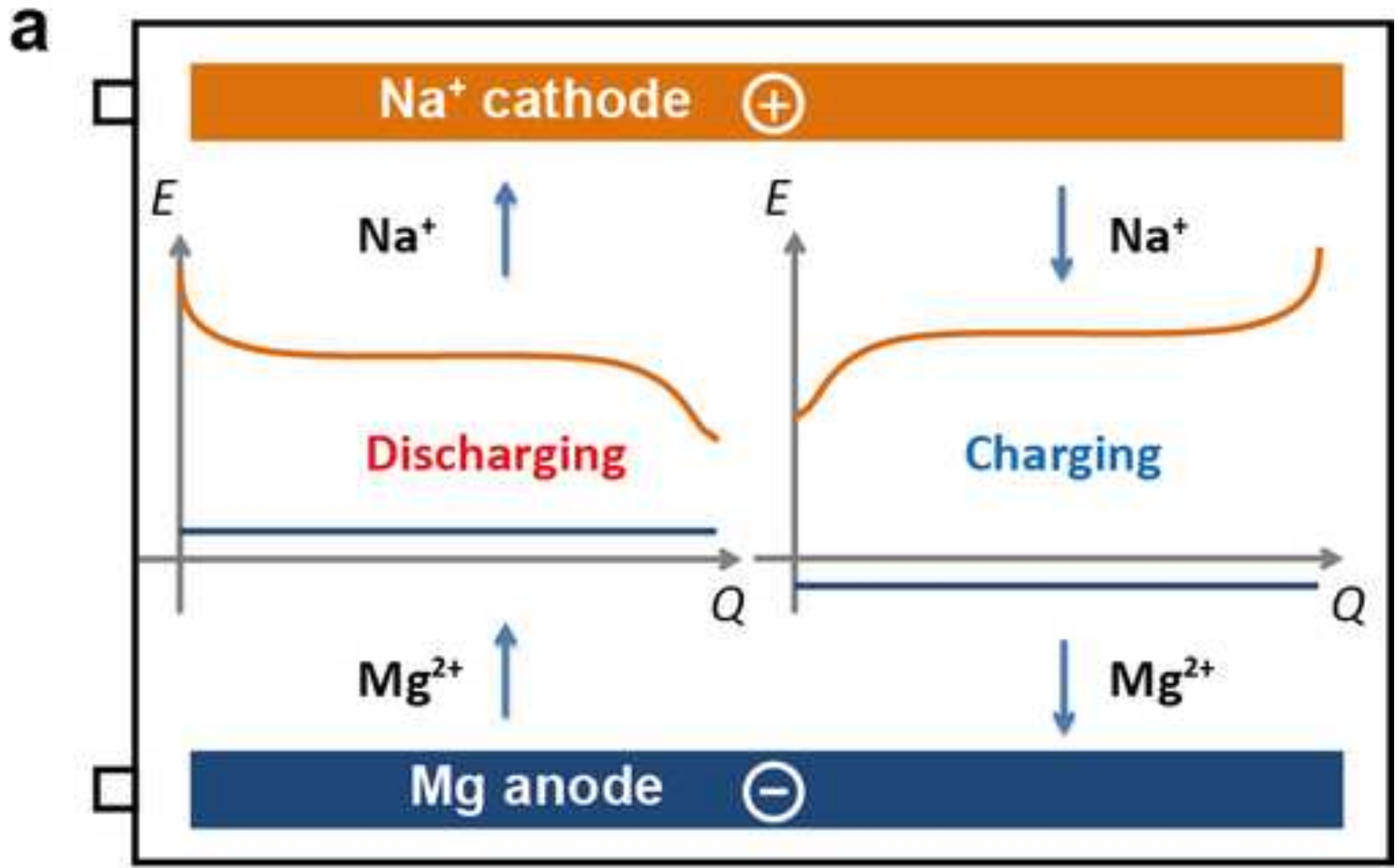

b

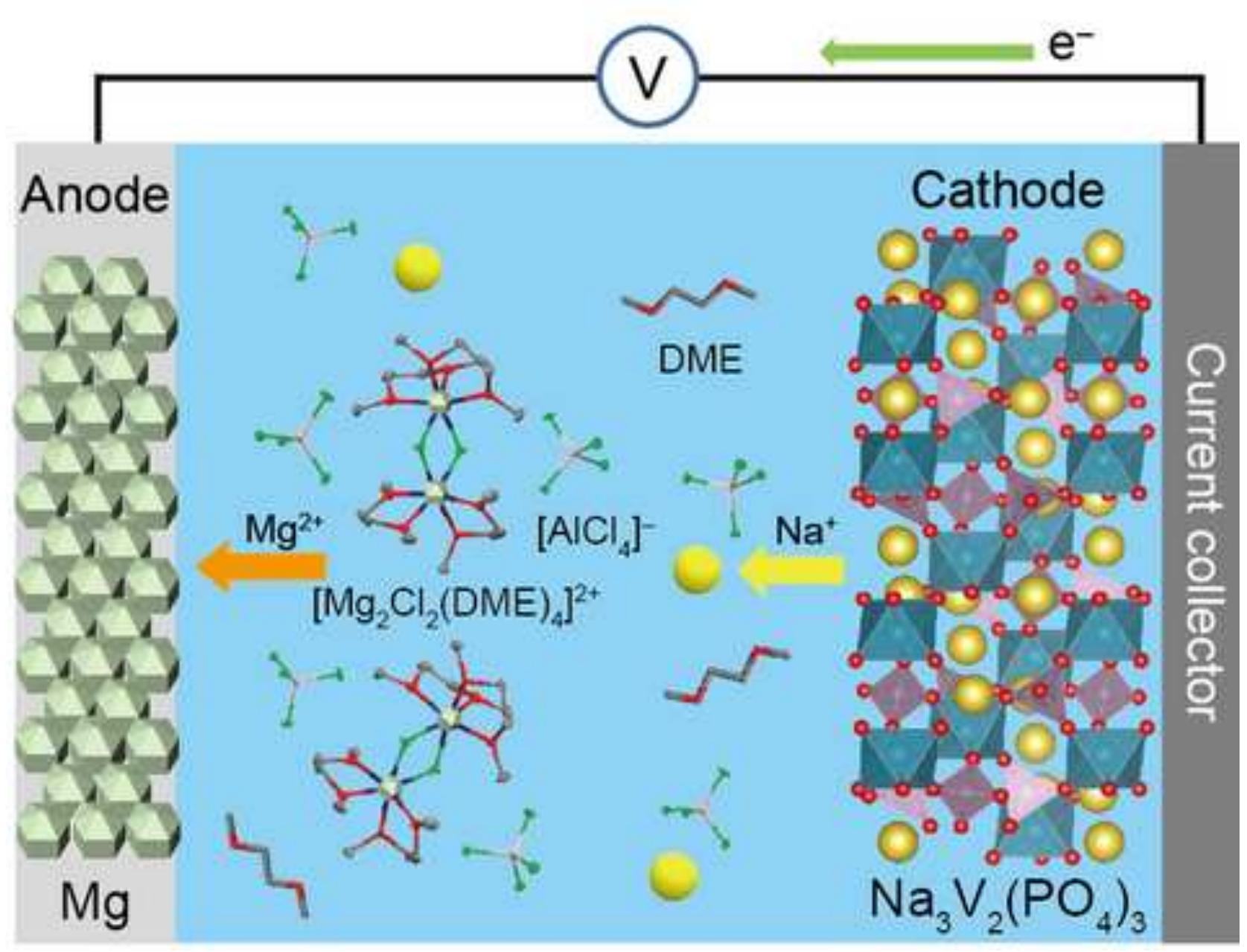



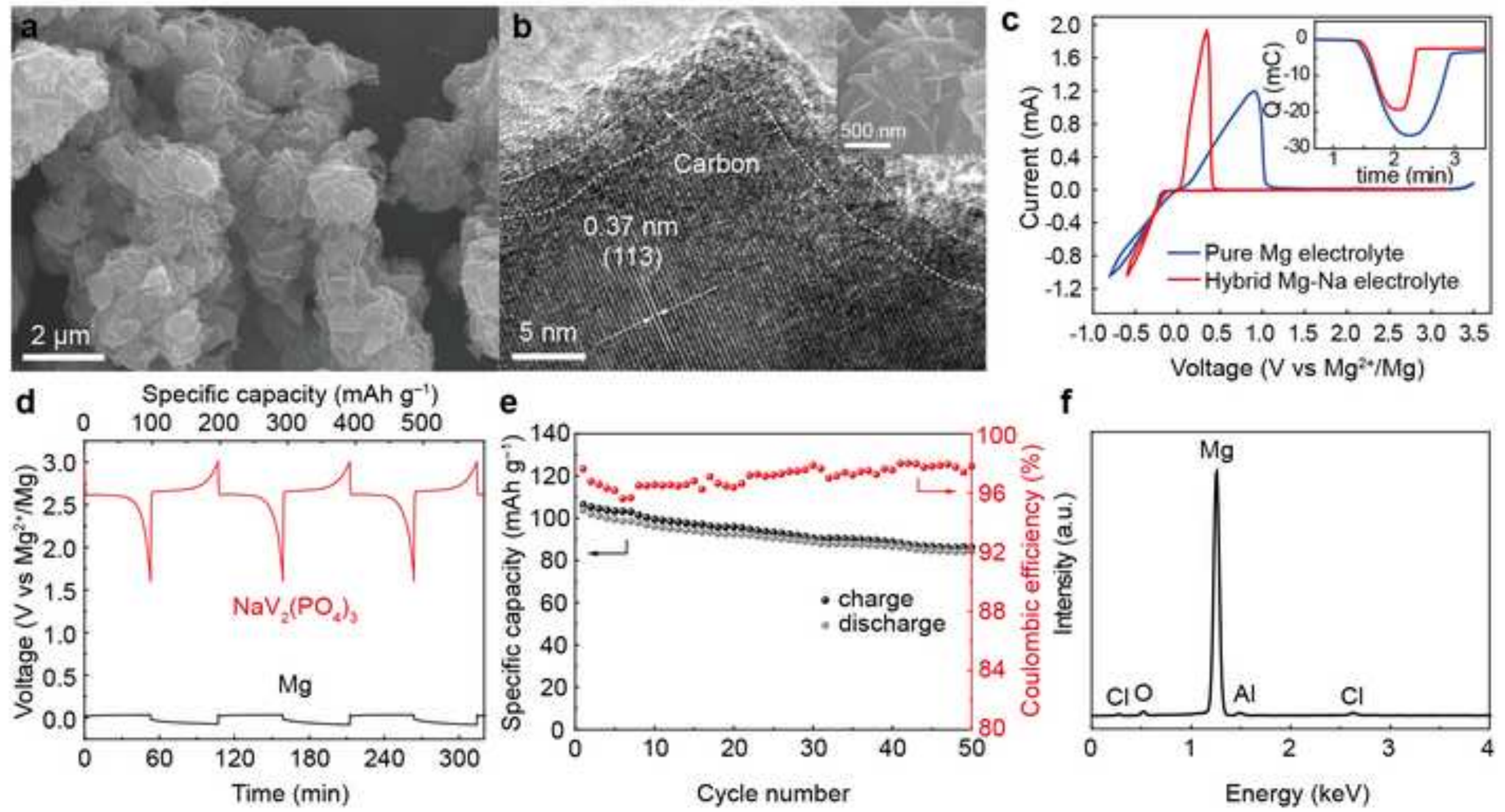
a
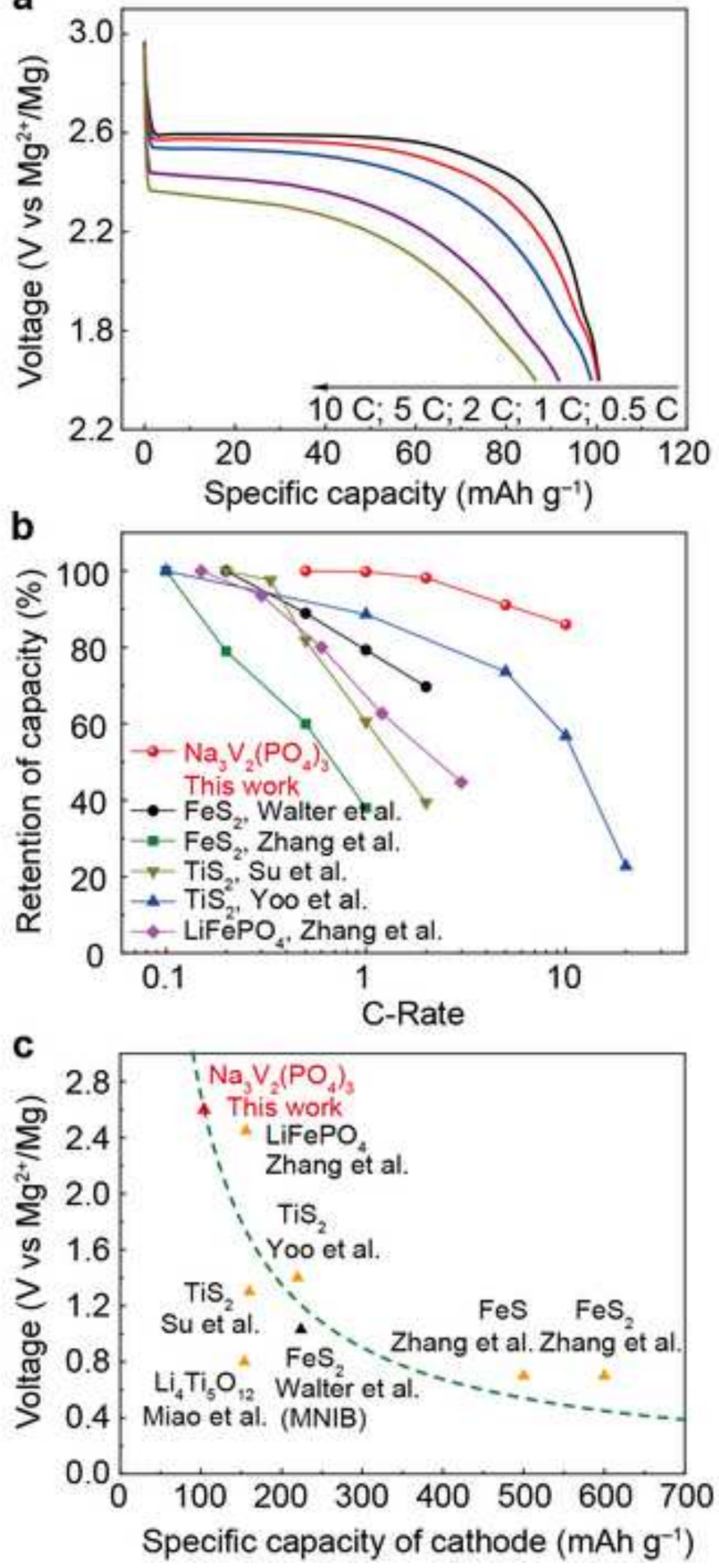
a
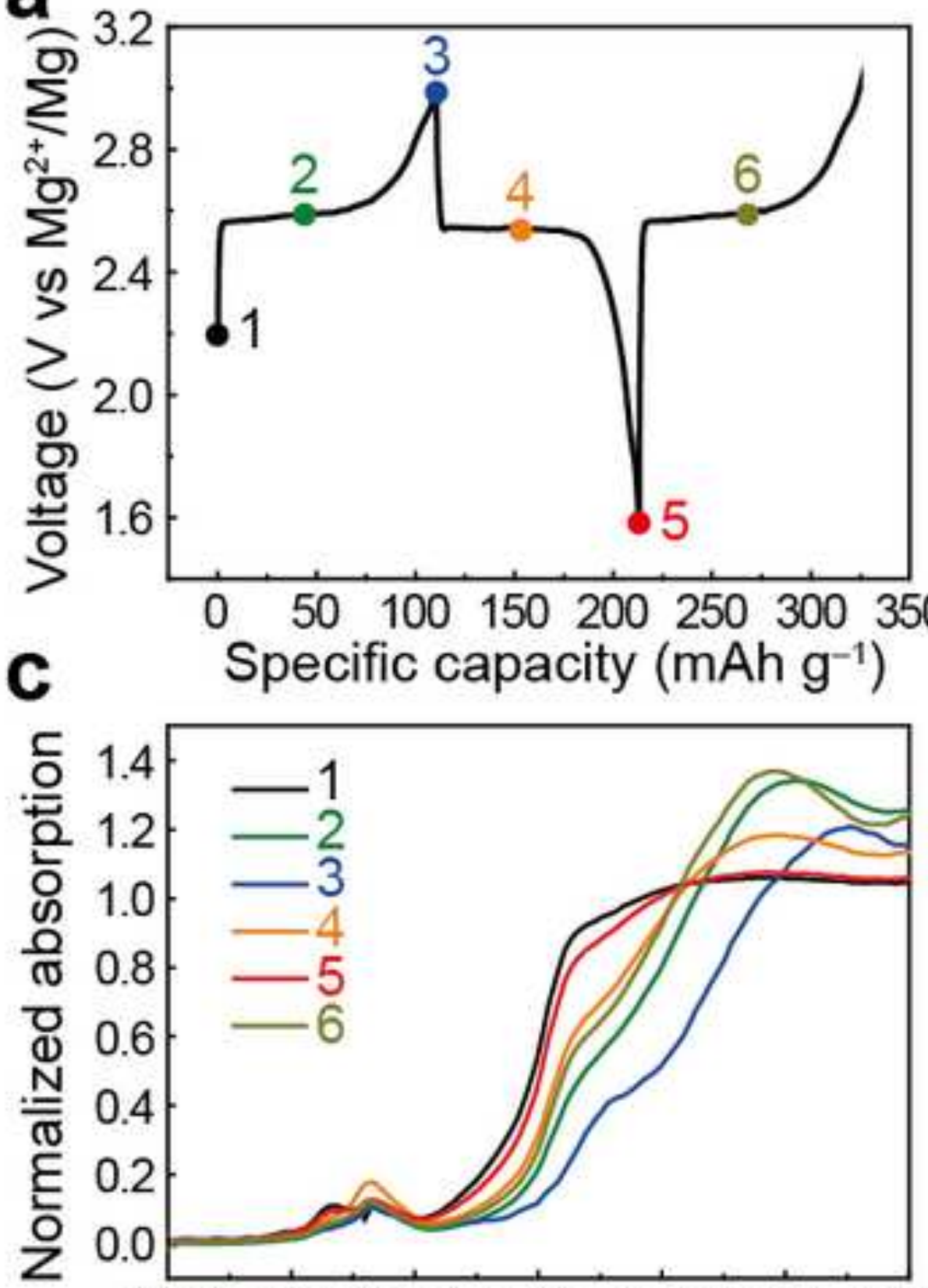

5460546554705475548054855490 Energy (eV) b

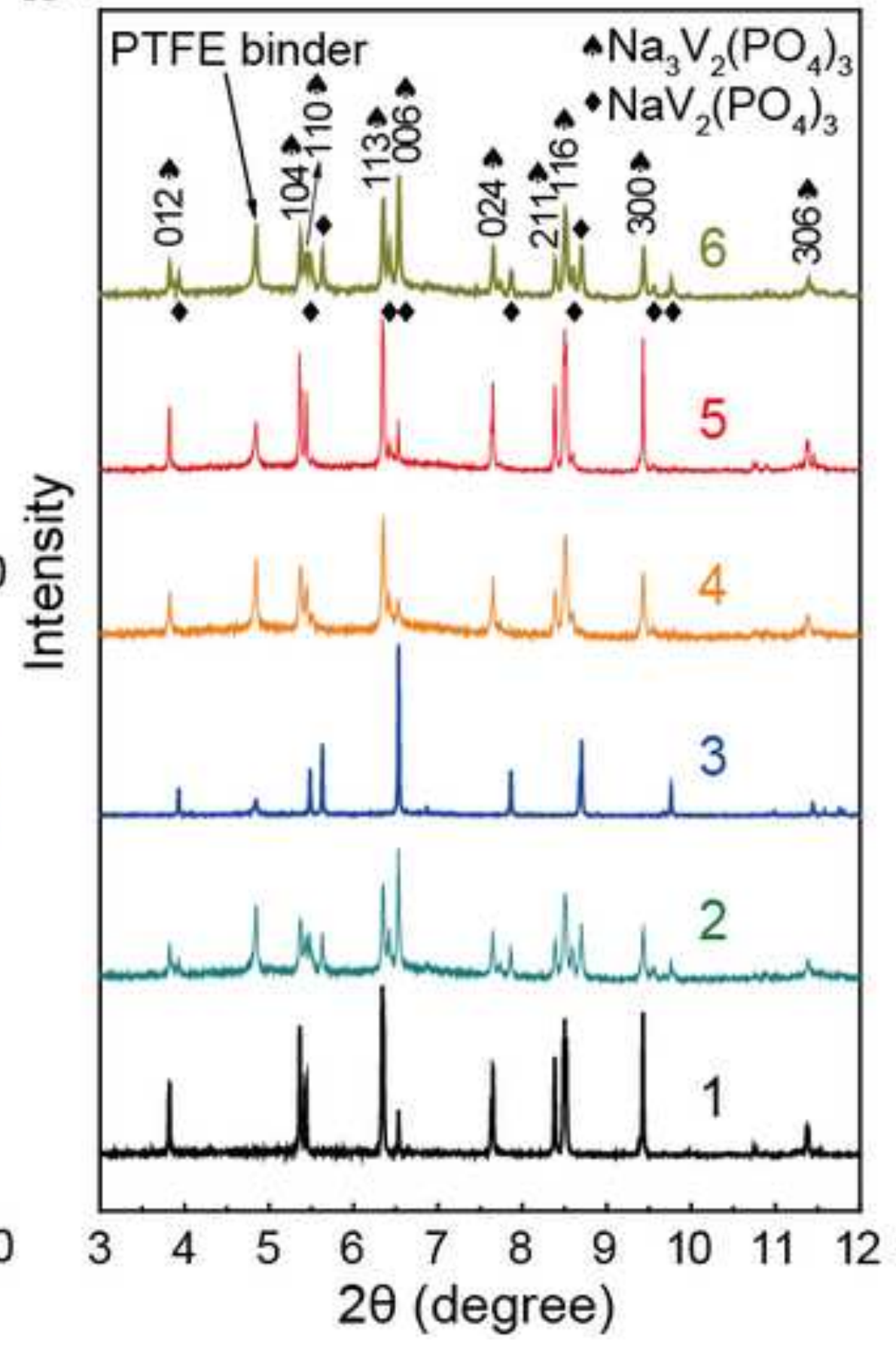


a

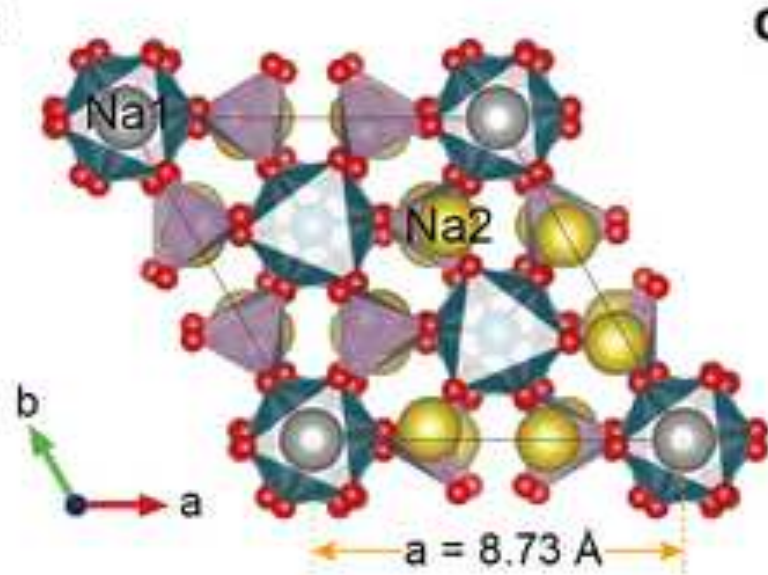

b

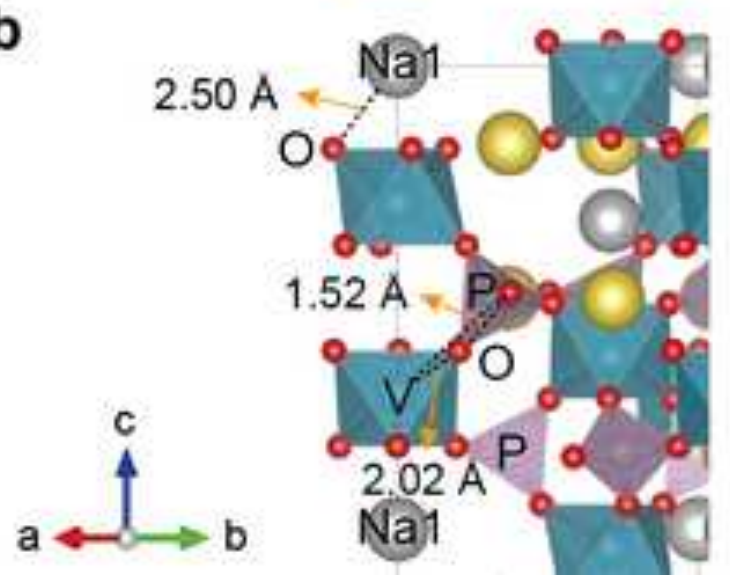

C

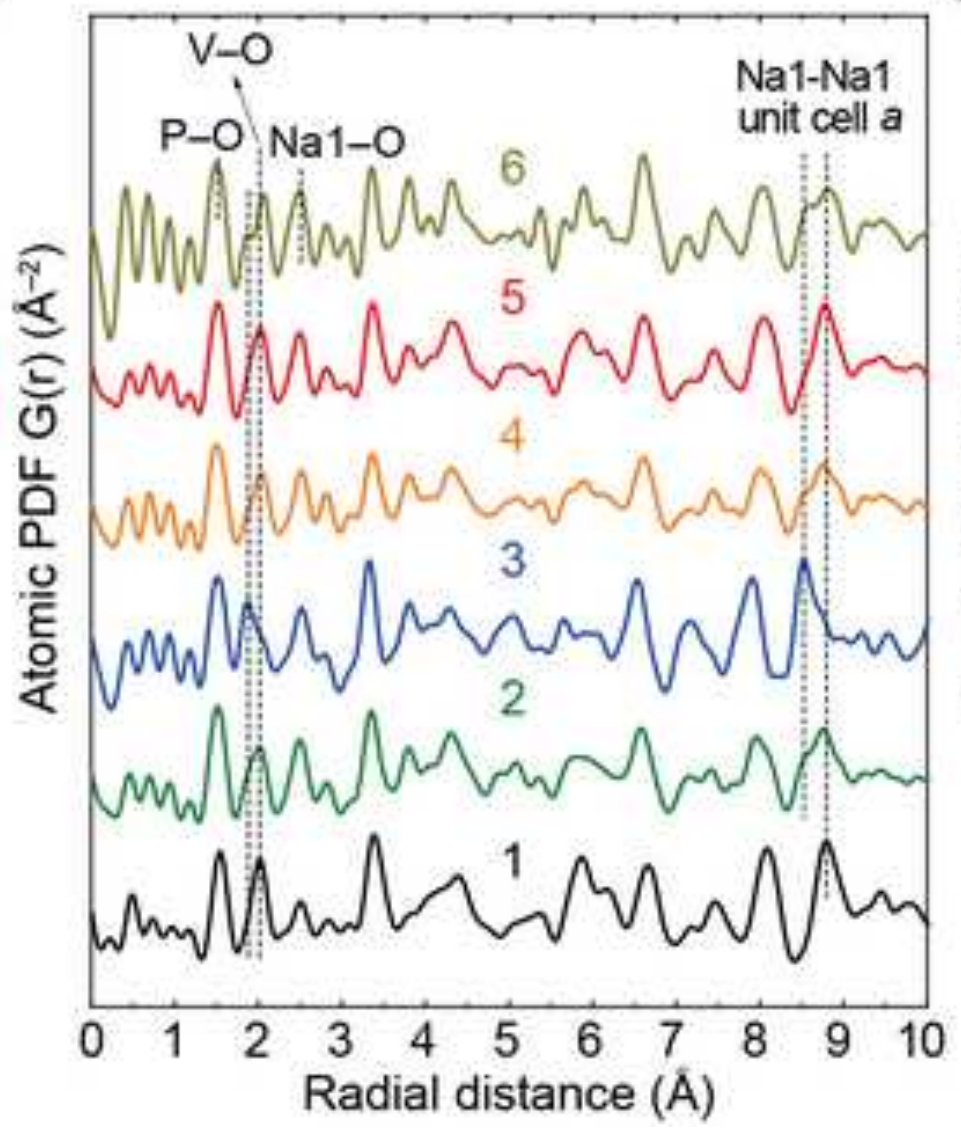

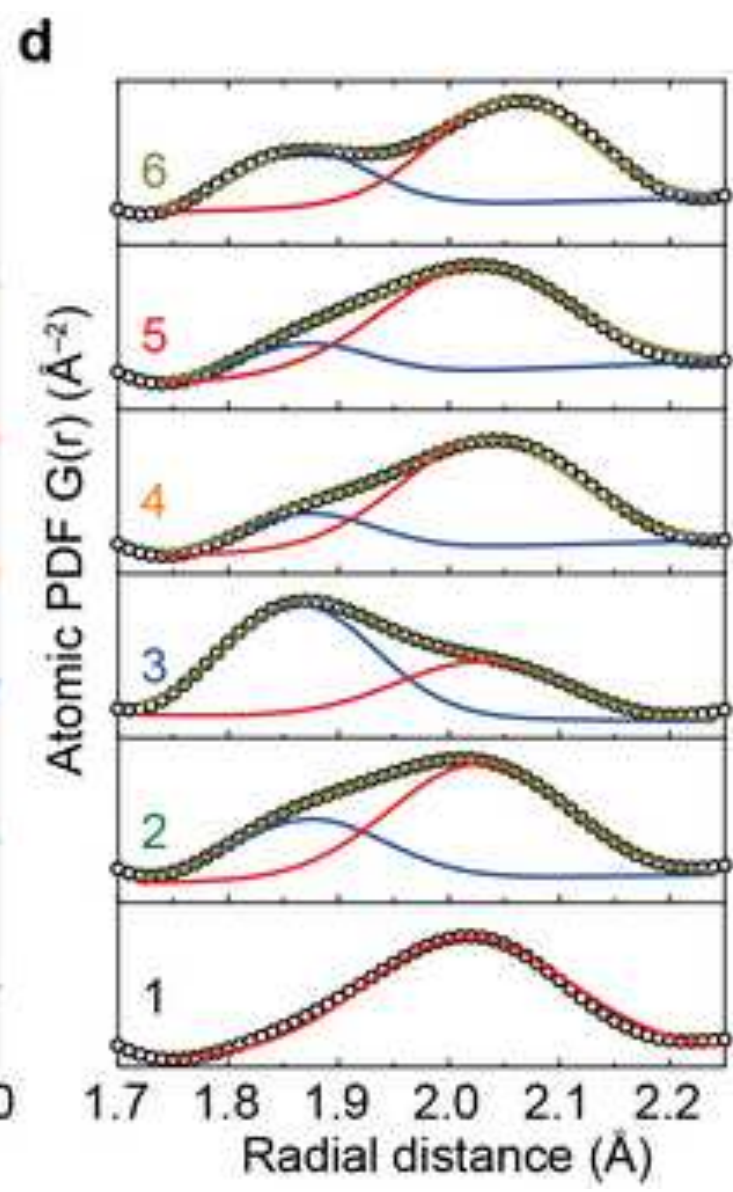


Revised manuscript with correction highlight
Click here to download Supporting Information: NVP Na-Mg hybrid_revisied with highlight.docx 
Graphical Abstract
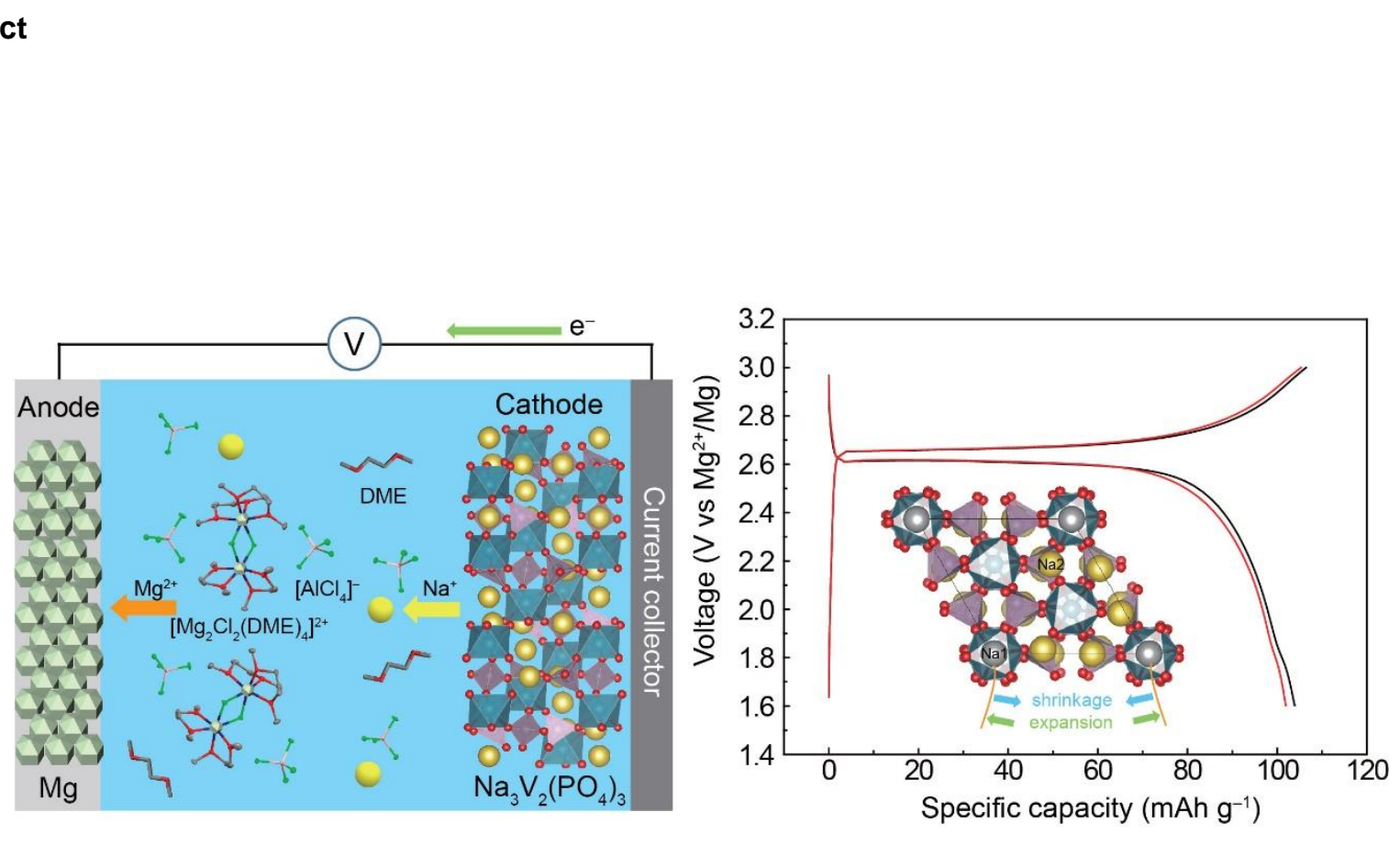